\title{
Univ. of
}

Tonastro LIBRARY 

IINDING LIST JAN 15 1922. 


\section{Digitized by the Internet Archive in 2007 with funding from Microsoft Corporation}




\section{GROWTH IN TREES}

BY

D. T. MACDOUGAL

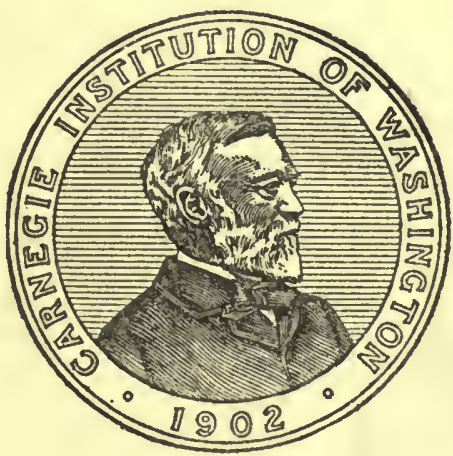

$\frac{169544 .}{27.2 .22}$

Published by the Carnegie Institution of Washington WAShington, 1921 


\section{CARNEGIE INSTITUTION OF WASHINGTON}

Publication No. 307

PRESS OF GIBSON BROS., INC.

WASHINGTON, D. C. 


\title{
GROWTH IN TREES.
}

\author{
By D. T. MacDodgal.
}

A tree may be considered as a tall cone of wood terminating in leafy expanses. The base of the cone is subdivided into myriads of rootlets, through the surfaces of which the soil-solutions enter, and the water, passing upward, is transpired from the leaves. The trunk of a tree is largely composed of dead cells, but inclosing it is a thin sheet of spindle-form cambium cells ${ }^{1}$ in 2 to 10 or more layers, which in the growing season enlarge in thickness and divide lengthwise, those on the outside becoming transformed into cork and phloem and those on the inner into wood cells and vessels. Extending from the center of the trunk are thin sheets or rays of the medulla or pith of the young stem. The most recently formed cells of these elements are still living and in some trees the medullary cells remain alive for several years, so that the woody cylinder of the tree may comprise wood-cells or tracheids, vessels, and thin-wall ray cells, some of which are alive. External to the cambium are sieve cells, bast fibers, etc., and cork cells, inclosed in a bark which varies widely as to structure in different species.

The greatest amount of increase or change in volume is that which results from the multiplication by fission of the cambium cells, and their enlargement accompanied by the differentiations mentioned, all based upon hydration of cell-colloids.

When changes in the entire diameter are measured the variations may be due to the action of any one of these tracts of tissue. The colloids of the cell, including those of non-living walls or wood, are practically never in a stable condition, but follow an ever-varying environment in resultant adjustments, especially with respect to the water which they contain. All plants except submerged forms are always losing water at a varying rate from part of their surfaces, while water may be entering absorbing surfaces at a varying rate, and as a consequence of the inequality the volume may increase or decrease according to the balance between gain and loss.

Growth in organisms is essentially a hydration of colloids of the protoplasm accompanied by metabolic changes which result in the conversion of materials in the cell-sap to the emulsoid condition characteristic of living matter. Both processes, one of adsorption and the other a result of shifting equilibria in chemical systems, cause an

1 Bailey, I. W. Phenomena of cell-division in the cambium of arborescent gymnosperms and their cytological significance. Proc. Nat. Acad. Sci., 5:283-285. 1919. 
increase of the volume of the protoplasm and an enlargement of the cell-mass of which it forms a part.

Any instrumentation of sufficient accuracy and delicacy to measure the increases or variations due to growth in the cambium layer will at the same time include the variations in volume of the woody cylinder, which is also the conduit through which liquid passes from the roots to the crown. Similar conditions prevail in nearly all higher plants, and growth measurements of all stems, leaves, and roots include changes in woody or non-living cells.

Such trees as the birch, with 200,000 leaves, are reputed to transpire as much as 400 liters in a single day. No estimates of the pines are available, but the low moisture content of the soil around the roots of the Monterey pine would not furnish a supply for such use of water. The trunk of a tree may, in fact, be compared to the supply hose of a fire-engine coupled to a hydrant. When the pressure from the mains is enough to supply water faster than it can be pumped out, the hose is distended. When the engine tends to take water faster than it would be delivered by the system, the hose would tend to collapse. Something of this sort takes place in many trees which have been kept under observation. The conduit in this case, however, is not a simple pipe or a set of pipes, but is made up of vessels, through which water may pass under capillary conditions, and inclosed box-like tracheids which may be only partially filled with water. When water is withdrawn from such a system faster than it is taken in, the resulting changes in form and size are complex in character.

These facts were well considered in my experiments previously carried out when the measurement of growth in trees was taken up in 1918, and a new technique with specially designed instruments was found necessary for the analytical study of the changes in volume of these massive organs. The records are now continuous for a large, number of trees for many months, one tree having been under continuous measurement since September 1919. The chief features considered in the present paper are as follows:

1. The dendrograph, an instrument for making continuous records of the variation of tree trunks, has been developed to an approximately final form. ${ }^{1}$ The essential feature of this instrument consists of a floating frame of metal of low temperature coefficient, such as invar or bario, which may be placed around a tree trunk, and the variation

\footnotetext{
${ }^{1}$ MacDougal, D. T. The dendrograph: a new instrument for recording growth and other variations in the dimensions of trees. Carnegie Inst. Wash. Year Book for 1918, pp. 59-60. The dendrograph. Carnegie Inst. Wash. Year Book for 1919, pp. 72-78.

The course of growth in trees as measured by the dendrograph. Carnegie Inst. Wash. Year Book for 1920, pp. 51-52.

Measurement of a season's growth of trees by the newly designed dendrometer. Carnegie Inst. Wash. Year Book for 1920, p. 52.
}

A brief discussion of the eontents of the present paper was given before the American Philosophical Society at Philadelphia, April 22,1921, which is in press in the Proceedings of the Society. 
in distance between a contact rod on one side of the trunk and of one end of a rod or lever on the other side is traced by a pen on the free end of a lever on a sheet of paper carried by a recording cylinder. Such measurements are in terms of the diameter.

2. A dendrometer, of simple design and non-expensive construction, has been perfected, which may be placed around the trunk of a tree and the size of the trunk read on a dial from time to time. The essential parts of this instrument are an encircling wire engaged with a number of bearing levers. One end of the wire is anchored and the other is attached to the short end of a lever, the free end of which moves over a scale giving readings of the size of the trunk in terms of several radii, or of the circumference.

3. Dendrographic records of trees have been made as follows:

Citrus aurantica: Citrus Experiment Station, Riverside, California; by H. S. Reed.

Fagus grandifolia: Baltimore, Maryland; by B. E. Livingston.

Fraxinus arizonica: Tucson, Arizona; by H. W. Fenner.

Juglans major: Carmel, California; by D. T. MacDougal.

Parkinsonia microphylla: Tucson, Arizona; by B. R. Bovee.

Picea pungens: Cottonwood Nursery, Wasatch Mountains, Utah; by C. F. Korstian.

Pinus chihuahuana: 6,000 feet altitude, Santa Catalina Mountains, Tucson, Arizona; by D. T. MacDougal and B. R. Bovee.

Pinus ponderosa: Alpine Laboratory, Pikes Peak, Colorado; by F. E. Clements and Gorm - Loftfield.

Pinus radiata: Seven trees, Carmel, California; by D. T. MacDougal.

Pinus scopulorum Lemmon: Fort Valley Experiment Station, Flagstaff, Arizona; by G. A. Pearson.

Platanus occidentalis: Missouri Botanical Garden; by B. M. Duggar and F. S. Walpert. Populus deltoides: Missouri Botanical Garden, by B. M. Duggar and F. S. Walpert.

Populus macdougalii: Continental, Arizona; by W. B. McCallum.

Pseudotsuga mucronata Sudworth: Alpine Laboratory, Pikes Peak, Colorado; by F. E. Clements and G. Loftfield.

Quercus agrifolia: two trees, Carmel, California; by D. T. MacDougal.

4. The trees noted above represented deciduous and evergreen coniferous types native to the Atlantic seaboard, the Mississippi valley, various elevations in the Rocky Mountains, the plateau, mountain slopes, and desert valleys of Arizona, the plains of southern California, and the coastal region at Carmel, with a wide variety of climatic conditions and seasons.

5. The period in which enlargement of trunks takes place is comparatively brief, even in places in which the season is of indeterminate duration.

6. Growth is an activity of an embryogenic tract of tissue, which depends upon environmental conditions, and no part of the observations suggested a seasonal rhythmic action. The Chihuahua pine, which exhibits growth of the trunk with that of the branches on the dry mountain slopes in the advance of the temperatures in May and June, is brought to rest coincident with the desiccation of the soil in the dry fore-summer. Reawakening ensues consequent upon the summer rains, and enlargement continues until checked by the decreasing temperatures and increased soil desiccation in the autumn. The 
Monterey pine (Pinus radiata) shows beginning growth of the trunks with the advance of temperatures, January to April, and comes to rest in July with the desiccation of the soil. Quercus agrifolia in the same region begins earlier and céases to grow in June or July. Both may be awakened in July or August by deep irrigation of the soil.

7. The trunks of all the trees measured show a daily variation in size, by which the maximum is reached shortly after sunrise and the minimum at a time after noon, dependent upon external agencies. Theso variations appear to depend upon the water-balance in the woody cylinder, are greatest in the seasons in which water-loss from the crown is greatest, are least in the cooler or damper seasons, and are to be detected in the records even in the period of most rapid enlargement of the trunk.

8. Measurement of variations in the woody cylinder were taken by arranging the contact rods of the dendrograph to bear on the wood formed by the tree two years previously. Thus, in 1920 holes were bored through the wood of that year and of 1919 and contacts made at the bottom of the cavities.

9. In general the awakening and growth of the terminal buds with resultant elongation of leaders and branches begins in many trees some time before enlargement of the trunk takes place. The period separating the two may be no more than a week in Quercus agrifolia and has been seen to be as much as 10 or 12 weeks in Pinus radiata. Observations on the Parry spruce and Douglas fir show that the trunks of these trees are enlarging at a time when the buds are in a very early stage of enlargement.

10. In the single case in which dendrographs were attached to a pine tree 1 meter and 8 meters above the ground, growth began coincidentally at the two places in 1920. In the following year, however, the dendrograph at the higher point on the trunk recorded enlargement a few days before any action near the ground was made visible. In February 1921 an auxograph was brought into bearing on the internode of a pine tree 5 or 6 years old which had been formed in 1919 . The buds had made a growth of 4 or $5 \mathrm{~cm}$., but no action had yet begun in the internode. A second instrument was brought into bearing on the middle of the internode formed in 1920 on another young tree. Steady enlargement was in progress.

11. The embryonic layer of a tree is in the form of an inclosing sheath terminating in the cones of the growing points. Activation of this tract is generally initiated in the growing points. Swelling in the cambium layer may be practically coincident with this awakening in some trees. Cases are recorded in the present paper in which weeks elapsed between the awakening of the buds and the enlargement of the base of the trunk. Activation of the growing cells may be taken to depend upon the localized food-supply, temperature, moisture, or other factors. 
12. Estimates of the range of daily equalizing variations in a Monterey pine taken from bearings on a thin layer of cork external to the bast of a trunk which had ceased to grow for the season show that the diameter might vary 1 part in 1,750. That a large share of this variation is due to changes in the hydration of the living cells is proved by the fact that when bearings are taken on the woody cylinder of the trunk internal to the growing layer the variation drops to 1 part in 8,750 of the diameter. The actual change in volume, in the first instance calculated on the basis of a conical trunk 18 meters high and $35 \mathrm{~cm}$. in diameter at the base, would amount to about $400 \mathrm{cu} . \mathrm{cm}$., of which not more than one-fifth, or $80 \mathrm{cu}$. $\mathrm{cm}$., is attributable to variations in the wood. It is to be noted, however, that the change in the volume of the wood may by no means be taken to represent the water deficit in the wood. The woody mass is made up of box-like cells, which may include a bubble of gas, the water forming no more than a thin film on the wall of the cell and inclosing the gas bubble in the eondition of extreme water deficit. The withdrawal of water through the walls of the cells, which are semi-rigid, increases the surface tension of the gas bubble, which results in a slight lessening of volume of the whole mass, but in an amount that would constitute no more than a small fraction of the total of the water loss.

13. Of 15 trees which were under dendrographic measurement in 1920, one each of Pinus scopulorum, Citrus aurantica, and Parkinsonia microphylla made no enlargement during the year. Such occurrences are to be taken into account in estimations of the ages of trees from the annual layers.

14. The greatest daily equalizing variations were shown by Fraxinus, Pinus, Picea, Pseudotsuga, and Juglans, and lesser variations were displayed by Populus, Platanus, Fagus, Quercus, and Citrus. No available facts furnish the basis of an adequate explanation of such differences.

15. The final effect of rainfall shown within a few hours is to accelerate growth, but it has been repeatedly observed that actual shrinkage may take place while the rain is falling. This action can not be traced to any instrumental error.

16. Irrigation of the soil which had a moisture content of less than 6 per cent around the roots of a Monterey pine was followed within 24 hours by progressive enlargement constituting growth at the base of the tree, and at a point 8 meters higher. The distance from the absorbing surfaces of the roots through which the added water supply must enter could not be less than 3 meters from the lower instrument, and the influence of the added supply was within the day felt at the upper instrument, 11 meters from the absorbing surfaces. It.does not seem possible that water could have been conducted through the tracheids this distance within the given length of time. 
17. An irrigation test similar to the above was made with a small California live oak (Quercus agrifolia). The results were even more startling than those described for the pine. Within two hours the dendrograph, which had its contacts with the tree at least 3 meters from the absorbing surfaces, showed some enlargement, an action which may be directly connected with the fact that the vessels in this oak are numerous and large.

18. The irrigation experiments might be held to simulate the effects of stream overflow which, if due to melting snows, would not be accompanied by any marked higher humidity. It is seen to result in the formation of a tapering shell of wood which was as thick as the seasonal formation at the base of the trunk, but which had but half this thickness 8 meters higher up on the trunk. The layer of normal formation was of practically identical thickness at the two places.

\section{HISTORICAL.}

The rate and course of growth in length of seedlings and plantlets of various trees have been the basis of many measurements, and the forester developed approximate methods for estimating the yearly or seasonal increase in the height or diameter of trunks. An interesting series of monthly measurements of a number of trees was made at San Jorge, Uruguay, in 1885-1890. Evergreen trees, including conifers, eucalyptus, and acacia, showed greatest increases in October, a spring month, and least in July (midwinter), while deciduous trees increase most in midsummer (December) and actually decrease in girth in autumn (May). ${ }^{1}$ Recently, also, some calibrations of the variations in volume of trunks correlated with temperatures have been made in New York. ${ }^{2}$ The available data, however, did not record the daily and seasonal changes or include information by the aid of which the activities of growing tips and branches might be correlated with changes in volume of trunks and stems.

The most notable attempt to follow accurately the variations in tree trunks previous to the instrumentation described in the present paper was that of Mallock in 1917. He used an apparatus consisting essentially of two plates of glass superposed, or an arrangement of prisms in connection with a tape of invar passed around the tree. Variations in girth caused displacement of interference bands of light. Observations on such displacements, at frequent intervals, showed that growth was greatest in the early part of the day, that actual contraction occurred in the afternoon, and that increases were closely related to temperature and rainfall. ${ }^{3}$

\footnotetext{
${ }^{1}$ Hall, C. E. Notes on tree measurements made monthly at San Jorge, Uruguay, from Jan. 12, 1885, to Jan. 12, 1890. Trans. Bot. Soc. Edinburg, 18:456. 1891.

${ }^{2}$ Trowbridge and Weil. The coefficient of expansion of living tree trunks. Science, 48:348-350. 1918.

'Mallock. A. Growth of trees, with a note on interference bands formed by rays at small angles. Proc. Roy. Soo., 80, B, 186-191. 1919. Submitted Dec. 1, 1917.
} 
This ingenious method would enable the observer to detect changes of 0.00005 inch in circumference, but as no recording devices are provided the constant attendance of the observer was necessary. Meanwhile my own results show that an actual amplification of 8 to 15 times the changes in diameter of the trunk is adequate for direct observation and analysis.

Friedrich had previously used a device for recording increments to the thickness of trees as early as $1905 .^{1}$ The tree was encircled with a steel band on roller bearings, and the ends were attached to both registering and recording arms. No cognizance was taken of errors due to changes in temperature, and no results obtained with this apparatus have been seen.

Some success having been attained in the measurement of the variations in stems such as those of the sunflower (Helianthus) and in the variations in volume of succulent stems such as those of Opuntia, by the use of mechanical levers, it was found desirable to extend the observations to trees. It was thought that accurate measurements of the changes in volume of these massive structures might not only give information of value on the subject of hydration and growth, but that some light might be thrown on the problem of ascent of sap.

The attempt to measure the variations in large trunks, begun in 1918, raised many difficult mechanical problems. First it was obvious that it would be practically impossible to hold the stem of any but small trees rigidly in any position. This made it necessary to devise means whereby the tree would support the instruments and carry them with it as it swayed and leaned. It soon became evident that such an appliance should consist of two parts; a base which would remain firmly in whatever position near the horizontal it might be placed about the trunk, and which would carry the more delicately arranged members of the second part which would register variations in diameter at some little distance from this base.

Two forms of base or support were devised and tested. One form consisted of a rectangular frame built up of bands of wrought-iron 2 by $1 / 4$ inches and of oak wood 2 by $2 \frac{1}{2}$ inches, which could be clamped about the tree tightly by means of an iron rod, including a heavy turnbuckle. A heavy block of seasoned oiled wood at one end formed a base for the levers and recorders and a wooden screw $30 \mathrm{~cm}$. long, working in a smaller threaded block hinged to the outer end of the larger base block, extended to a point on the trunk several centimeters below and formed a brace which kept the block rigid in its position with respect to the tree. Flexible supports carried a floating frame which served to register variations in thickness. This form of base was heavy, unwieldy, and by reason of the metal was subject to temperature variations which might influence the record.

${ }^{1}$ Friedrich, J. Zuwachsautograph. Centralb. für das gesammte Forstwesen. 31, pp. 456461. Nov. 1905. 
The second and preferable form of base may be described in a phrase as a belt of wooden blocks hinged together. Seasoned and oiled blocks of redwood (Sequoia sempervirens), 15 by 7 by $7 \mathrm{~cm}$., were bound together in a belt by pairs of galvanized strips of iron. Small bolts passed through the ends of these strips and through holes near

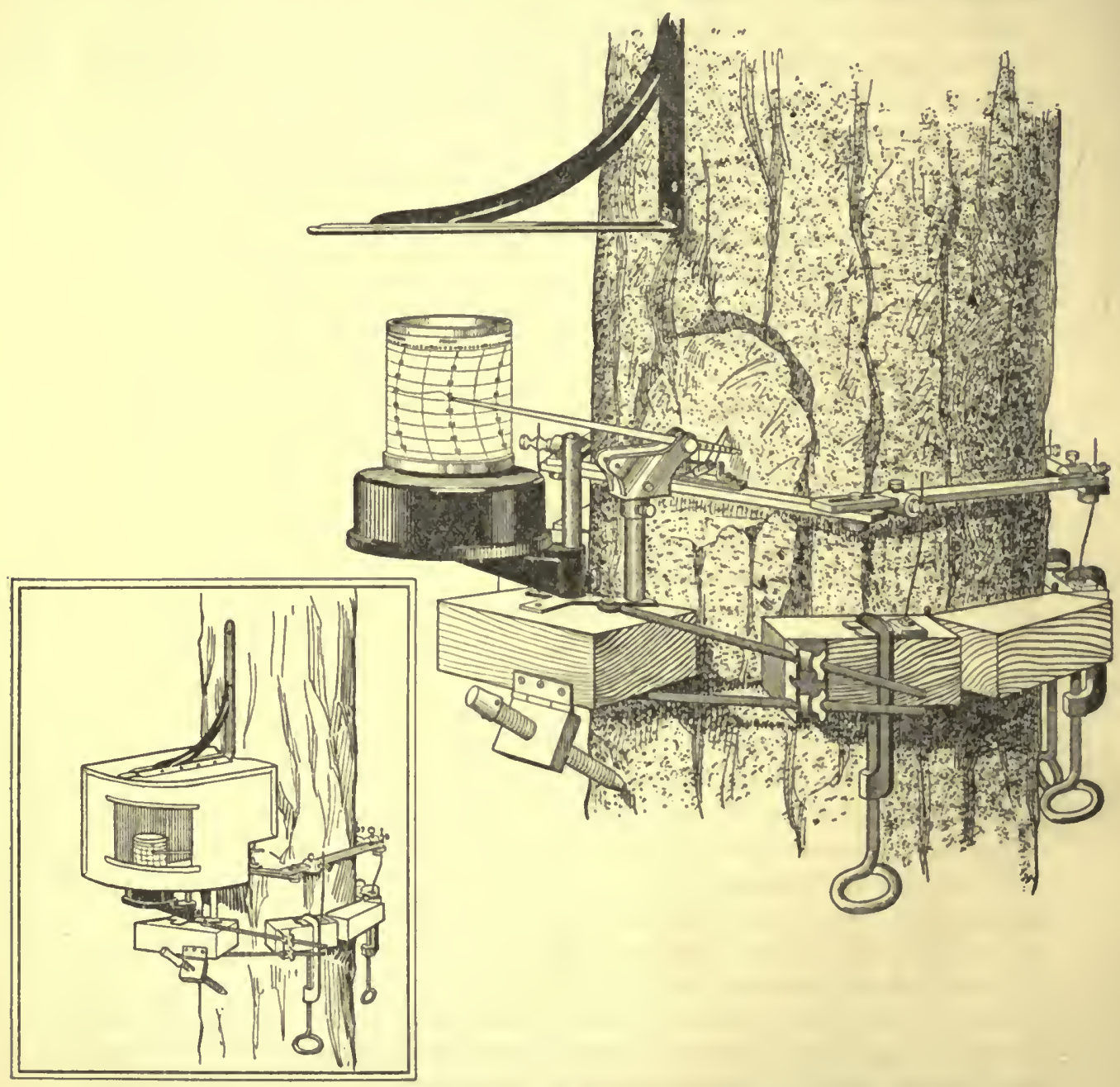

FIG. 1.-Earlier form of dendrograph with which all records previous to September 1920 wero made. This instrument takes a bearing from a prepared area on the bark of the tree by one end of a small lever, the other end of which is connected with the short arm of a recording lever. The improved instrument includes a lever set, in which the bearing on the tree is made by a horizontally moving quartz rod, as shown in fig. 2. An encircling belt of wooden blocks serves as a base and support. Flexible wirc standards, with a base of thin sheet metal, are clamped in position on the wooden blocks, and screw clamps which slide up and down on the wire standards aerve to hold the floating frame in a horizontal position. The entire apparatus is so adjusted that a contact rod on the opposite side of the tree is held with gentle pressure against the tree and any variation in diameter is then expressed by movements in the lever get. 
the end of the blocks were easily put in place or removed, so that any number of blocks might be joined to form a support which would encircle a tree of any size. From 4 to 9 blocks were used in most of the instruments. A wooden block of larger size, carrying an upright rod $10 \mathrm{~cm}$. long as a support for the recorder, was used to close the support or form the buckle of the belt. The actual fastening, however, consisted of a pair of threaded rods extending from the large block and resting in the slots of angle irons on the small end block. Nuts of suitable form could be turned on these threaded rods until a suitable tension had been put on the belt (see fig. 1). A long wooden screw, working in a small block hinged to the outer end of the instrument base, forms a supporting brace as in the other form of support. When such a belt base is drawn tightly about a tree of the sizes measured, the eight or nine blocks used adjust themselves to the irregularities of the trunk, but in general assume a tangential position and press tightly on the bark and cambium internal to it, but the total disturbance by such pressure is small and does not affect the changes in the volume of the portions of the trunk actually measured, a few centimeters higher.

The essential feature of the apparatus is the floating frame which makes two contacts with the trunk. One such contact is made by a set screw, carried by this frame, which may be turned to a point where it makes a slight but firm contact on the trunk. The second contact is made by the quartz-bearing rod of the lever-set carried on the floating frame at a point diametrically opposite to the contact screw. Any change of the trunk affecting the distance between the end of the contact screw, which is immovable on the floating frame, and of the sliding quartz rod of the lever system or set would be expressed in the movement of the pen lever which traces a line on the graduated paper sheet carried by the revolving cylinder.

The first instruments were constructed at a time, during the Great War, when it was impossible to procure the alloys which have a low temperature coefficient. Floating frames of wood and iron were constructed in a $U$-shape. The curved ends of the $U$ consisted of a bar of wrought iron, 1 by $1 / 4$ inches, fastened by bolts to the sides of the $U$, which were of seasoned oak boiled in paraffin. The oak bars used for the frames of the carriage tops were found suitable for this purpose and (as they were 3 by $2 \mathrm{~mm}$. in cross-section) are sufficiently rigid. The instrument bar was a strap of iron with the ends turned at right angles to be parallel to the wooden bars. These short arms are slotted so that the instrument bar may be fixed in position at a suitable distance from the trunk. Cold would cause the curved iron member of the frame to be drawn toward the tree, and as the turned ends of the instrument bars run from the tree their contraction by cold would cause a movement which would tend to maintain an equal distance between the two and leave uncompensated only the temperature varia- 
tion of the wooden side arms. As the temperature coefficient of such wood is about 0.000054 , or 3 times as great as that of brass, extensive and difficult corrections were necessary.

The U-shaped floating frame was retained during the earlier stages of development of the dendrograph, and this form has some desirable features, especially when the record of a slowly growing tree is to be obtained for a long period. Such frames have now been used in securing records of growth of Pinus radiata No. 1 for two seasons; however, the enlargement is at such a rapid seasonal rate that the frames must soon be replaced.

The final form of the floating frame is that of a polygon constructed of strips or bars of invar or bario, 15 to $30 \mathrm{~cm}$. in length, 3 to $5 \mathrm{~mm}$. in thickness, and 12 to $15 \mathrm{~mm}$. in width. These pieces have slots near each end, about 5 to $8 \mathrm{~cm}$. long, through which short bolts are passed. When five to eight such strips are joined to form a suitable frame about a tree, the nuts on these bolts are tightened and the joined parts are held as rigidly as of one piece. One of the members of the floating frame carries a block of metal welded to it and bored to receive the contact screw which is provided with a set nut. The member of the floating frame which is nearest the instrument block carrying the recorder is bored to receive the small bolts which carry the lever set designed especially for this instrument.

The essential feature of this lever set is a quartz rod, 3 or $4 \mathrm{~mm}$. in diameter, 7 or $8 \mathrm{~cm}$. in length, which slides in holes of the vertical arms of the adjustable frame of the set. The outer end of this rod is fitted with a slotted cap or guide by which its rounded end is kept in place against the short arm of an L-shaped lever. The long arm of this lever carries a pen of the type used on thermographs. The dropped arms of the frame which carry the sliding quartz rod have three pairs of holes, so that the rod placed in the lowermost holes engages the short arm of the lever near its end, thus causing the least amplification of its movement in the record, which is ordinarily about 10 times. The rod when placed in the middle pair of holes causes the pen to move through an arc 15 times as great as the motion of the rod, and when placed in the uppermost holes the bearing against the short arm of the lever is so near the pivot that an amplification of 22 is made in the record. The actual amplification is of course tested for each instrument. The metal parts of the lever set are of monel, since this avoids corrosion and the construction (as shown in fig. 2) is such that all of the necessary adjustments are made possible by sliding the parts of the frame upon each other

The recorder is also of a design perfected for use with this instrument. A strong clockwork is inclosed in a heavy case. The upwardly projecting end of the main arbor of the clock is fitted with a cap overjutting in such manner that, when in place, water coming down as 
rain does not enter the case. A circular table or base is fitted to the cap, and a drum made of a section of large brass pipe sits directly on this fitting inside its raised rim, so that it may be removed without disturbance of the clockwork.

The new feature of importance of this cylinder is the manner in which the record paper is attached. The paper is $80 \mathrm{~mm}$. in width and

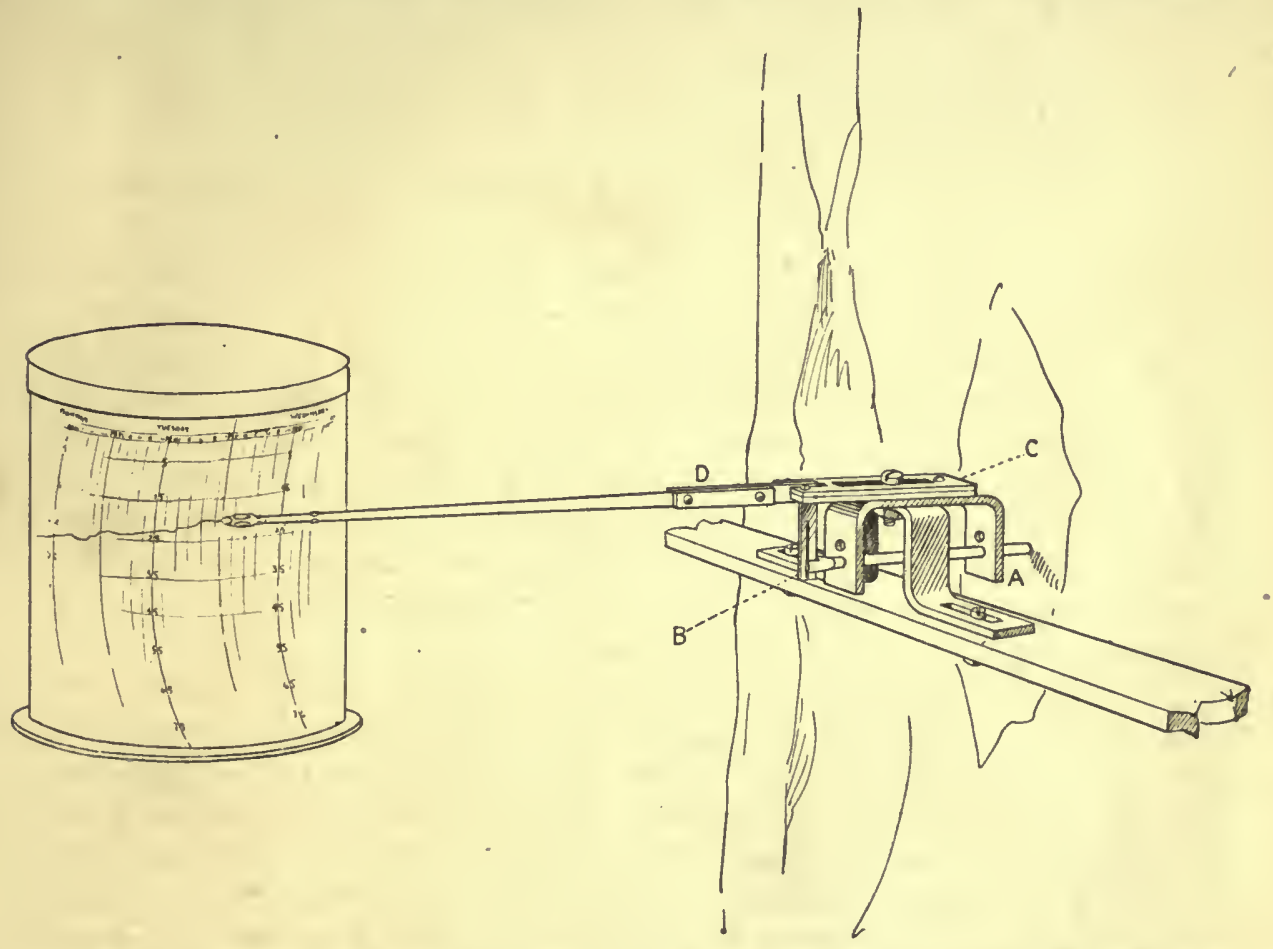

FIG. 2.-Improved dendrograph lever set. $A$, inner end of quarts rod in contact with prepared surface on the bark of the tree. The outer end of the quartz rod is fitted with a metal guide which engages the short arm of the recording lever at $B$. The long arm of the recording lever, $D$, carries a pen which makes a tracing on ruled paper on a revolving drum. The horizontal member of the frame $C$, which carries the recording lever, may be toward or away from the tree to adjust the pen at any point on the paper record sheet.

ruled to millimeters. When placed on the drum the ends are thrust through a slot $1 \mathrm{~mm}$. in width and the free ends are creased on the inside without further fastening. When the drum with the paper so attached is set on its circular base the paper is properly in position when its lower edge is in contact with the rim of the base. A covering as described below is placed over the recorder, but in any case actual rain falling on it would mar only the record and could not damage the instrument.

The floating frame, however, is exposed to all features of the weather and to the effects of sunlight which might cause its temperature to vary from about $0^{\circ} \mathrm{C}$. to $25^{\circ} \mathrm{C}$. during the growing season of the trees 
measured, and if the variations were to be recorded during the entire year the range would be even greater. The change in dimensions of a floating frame of invar arranged in the form of a polygon with a total perimeter of $60 \mathrm{~cm}$. may be estimated from the following data. The temperature coefficient of this metal is 0.00000015 per degree, and the daily range of air temperature does not vary beyond $25^{\circ} \mathrm{C}$., usually much less. The daily rise in temperature of this yoke, which would tend to increase its radius and to make the daily shrinkage of the tree appear to be greater than it really is, would therefore be found by the following formula:

$$
E=\frac{V(0.7 \times 10 c) 600}{\pi}
$$

in which $E$ equals expansion and $V$ the range of variation. $E$ therefore is equivalent to $25 \times 0.0000007 \times 600$ divided by 3.1416 . The possible enlargement of the diameter of the yoke, if the temperature rose from $10^{\circ}$ to $35^{\circ} \mathrm{C}$., which would be a maximum, would be no more than $0.0036 \mathrm{~mm}$. Part of this is practically compensated by the radially arranged contact screw of invar which projects inwardly $30 \mathrm{~mm}$. It is to be seen that when this error is amplified 12 times it could amount to no more than about $0.04 \mathrm{~mm}$., which would not be a discernible interval on the record. The use of invar or bario may be taken to furnish a floating frame, the variation of which would be negligible in measurements of variations in the trunks of trees.

One additional feature of the instrument yet remains to be described, this being the devices by which the floating frame is kept in its horizontal position around the trunk. This is accomplished by a series of clamps and upright flexible wire supports. Sections of bronze wire or bronze-coated steel wire, about $10 \mathrm{~cm}$. in length, are fastened to a foot or base of brass 3 by $5 \mathrm{~cm}$. Such supports are placed in suitable positions on the upper surfaces of the wooden blocks of the encircling belt and fastened in place by clamps of proper size. Each upright wire carries a small brass clamp which may be moved up and down and fastened at any point. The free end of this clamp is slotted to receive the flat members of the floating frame which are fixed firmly in place by set screws. Adjustments of positions of the wire supports and of the clamps on the members of the floating frame are made until the last named is held in such position that the contact screw exerts a small amount of pressure on the trunk, so that any variation will be expressed by movements of the quartz rod of the lever set on the opposite side of the tree.

The adjustment of the contacts is a matter of some nicety. A broad chisel may be used to slice away the bark until a thickness of not more than a millimeter remains outside of the living tissue, over an area about equal to that which might be pressed lightly by a finger tip. 
Actual adjustment of an instrument in this manner is a work of about an hour. During all of this time the recording lever has been kept in a vertical position. It is now lowered until the short arm engages the guide on the quartz rod and is in good contact. The recorder is now swung around until the paper on the drum is brought against the pen, being rotated to begin tracing on the proper day and hour. With pens properly inked, a complete record for a week may be obtained without further attention.

Not all of the results cited were obtained with the instrument described above, which has been in use only since September 1920, but the earlier records have not been used in any manner in which their faults might vitiate the general discussions and conclusions founded on them.

\section{THE DENDROMETER.}

The records made by the dendrograph show the volume or diameter of the tree at any moment and the variations which have taken place in reaching these dimensions. Such observations are indispensable to any searching study of the course and physical basis of the growth procedure. It is also important to determine the total amount of growth which may have taken place in a trunk during a season or a period of years. Such an instrument would serve to check the detailed records of the dendrograph and would have direct usefulness in the determination of the increment in trees grown for timber.

An instrument of this kind, which might be read only at the beginning or end of a season, could be constructed of common materials without regard to the temperature coefficient of the members. Such an instrument, known as a dendrometer, was designed in 1920 and a number of models have been in attachment to trees since May of that year. ${ }^{1}$

The principle of an encircling wire carried by a number of plungers, originally tested for the dendrograph in 1918, was utilized in the construction of the dendrometer. Such a device was unsuitable for the recording instrument, as it was impossible to secure a wire of sufficient flexibility with a low temperature coefficient. As noted, however, this objection had no weight in the simpler instrument, which was to be read at long intervals. The first assembly of this instrument, consisting of a belt of blocks linked with strips of galvanized iron $125 \mathrm{~mm}$. long, $40 \mathrm{~mm}$. wide, and $0.8 \mathrm{~mm}$. in thickness, bearing guides for five radially arranged plungers, was fastened to a Quercus

\footnotetext{
1 It is to be noted that the term dendrometer has been applied to instruments used by the forester by which the diameter of trunks is taken by direct observation, the observer sighting at the part of the trunk to be measured. See D. Bruce: A new dendrometer, Univ. of Calif. Pub., 3, No. 4, pp. 55-61, 1917.
} 
agrifolia, $75 \mathrm{~cm}$. in circumference, on May 28, 1920. Spliced banjo wires of silvered steel were run through the outer ends of these plungers or contact rods, one end being anchored in such manner that slack could be taken up and tension adjusted; the other end was taken around a small pulley, one radius of which was prolonged by a pointer $15 \mathrm{~cm}$. long. The radius of the pulley was $0.5 \mathrm{~mm}$. Five contact points were arranged on the tree which would allow this instrument to show variations in as many radii. Six months later the tip of the pointer had moved through $110 \mathrm{~cm}$. and as the amplification was 30 , the actual enlargement of the perimeter of the polygon made by the wire was $\frac{11}{3} \mathrm{~cm}$., which was due to the action of the tree in 5 radii. This elongation being of the circumference, the average elongation of a radius would be represented by

$$
\sqrt{\frac{11}{3} \times \frac{1}{5} \times \frac{1}{3.1416}}= \pm \text { nearly } 0.5 \mathrm{~mm} .
$$

This would imply an enlargement of a millimeter in thickness. It is to be noted that the observation was begun at a time when the tree had made the greater part of its growth for the season.

After a series of trials of a wide variety of devices, a final design was adopted in which the support was a narrow band of galvanized iron or a belt of heavy wire bent in undulating folds, the ends being securely brought together by slender threaded rods working in slotted angleirons attached to the ends of the belt. Sections of copper tubing or copper rods, $15 \mathrm{~cm}$., long, are bent into the form of an L. One arm, $10 \mathrm{~cm}$. long, is flattended and perforated for attachment to the belt or support. The other arm is in a position radial to the tree and the spring-like action of the long arm presses its end gently against a prepared spot in the bark. A pointer and dial are attached to the support at the point where the ends are brought together. One end of a piece of nickel wire, about 28 or 30 gage, is anchored to a post on the dial, and the wire is led around the tree, passing through suitably smoothed holes in the short arms of the copper arms or plungers, and the free end is attached to the short arm of the pointer (fig. 3).

Adjustment of either end of the wire is made so that a delicate but positive pressure is exerted by each plunger on the surface of the trunk and the pointer is at zero, or at some datum point duly noted. Such instruments are inexpensive, so that they might be used in large numbers in any serious attempt to measure increments of timber trees, and would need very little attention. It is to be noted, of course, that they may be subject to accidents from falling branches or large animals; or, 
if the wire has been kinked.in adjustment, breaks may occur after a few days at ordinary tensions.

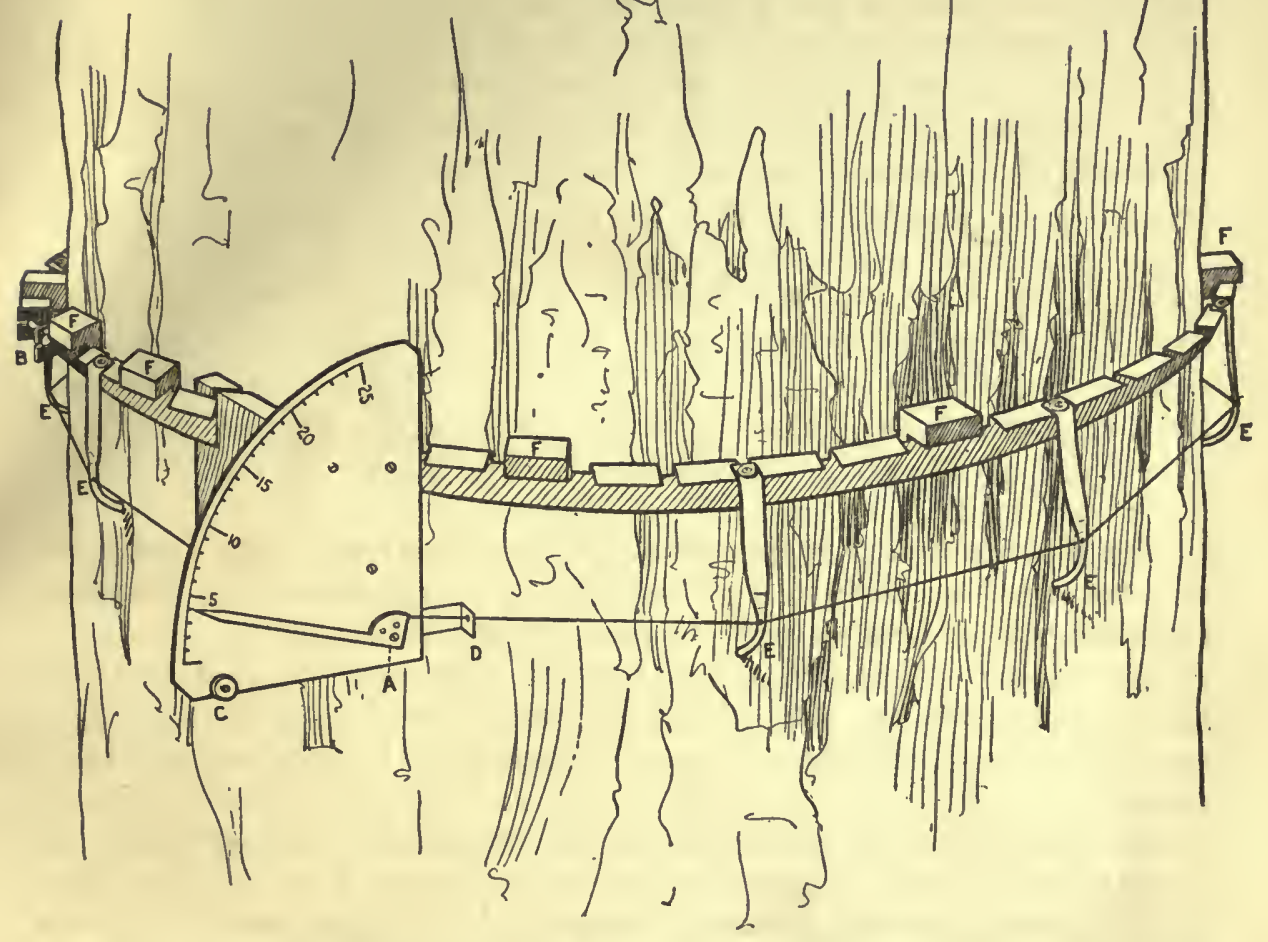

FIG. 3.-One form of the dendrometer. An encircling band of galvanized steel strip is brought together at $B$ and rests upon wooden blocks bearing on the bark at $F, F, F, F$, etc. An encircling wire passes through suitable holes in flexible arms attached to the supporting steel strip. This wire is anchored to a post on the inner side of the dial, the other end being attached to the short arm of the indicator at $A$. The enlargement which has taken place has pressed the flexible arms outward, pulling on the wire to such extent as to cause the indicator point to move from zero at the bottom of the scale to " 4 ."

\section{MEASUREMENTS OF PINE TREES.}

The Monterey pine (Pinus radiata) is native to the maritime climate of the fog belt of the Monterey peninsula and the slopes of the Santa Lucia mountains to the southward; and, as numerous trees of all ages were available on the grounds of the Coastal Laboratory at Carmel, it was selected for an intensive study of the growth of the pines.

This tree is characterized by extremely rapid growth, both in length and thickness, and does not survive to an age of more than about 80 years. The staminate and pistillate flowers are matured late in January and the pollen is scattered in February. Elongation of the 
tips of the branches, especially of young trees, begins about this time and such growth may continue until September, according to Dr. Forrest Shreve, ${ }^{1}$ who reports that records of elongation of as much as 10 feet of the leaders of young trees are in existence. Dr. Shreve has also described the features of the trunk, but an example examined by the author will serve to illustrate the structure of such trunks. This tree was about 12.5 meters in height, $15 \mathrm{~cm}$. in diameter a meter above the ground, and had 12 layers of wood in the heart and 18 in the lightercolored sapwood. The heaviest increments to the trunk, according to Dr. Shreve, occur in the period of development between 10 and 20 years of age, at which time very heavy layers of wood may be formed.

Dendrographic measurements of the variations and growth of the trunks of nine trees in the grounds of the Coastal Laboratory have been made since September 1918. A continuous record of the basal section of the large tree upon which the observations were begun has been kept since that time, and a second instrument was attached to this tree 9 meters above the ground in March 1920, so that a double record for an entire season is now available.

The seasons in the region in which the Monterey pine grows are indeterminate as to frost and temperature features, but the rainfall occurs in the winter and growth is seen to depend upon the soil supply of water and the rising temperatures, with the result that enlargement of the trunks continues until the soil moisture around the absorbing roots is depleted until it forms no more than 6 to 10 per cent of the total weight.

The present studies have been devoted chiefly to changes in volume of trunks and so many technical problems have been encountered that no attention has been paid to the features of development of the cambium inclusive of the periods of cell-division, of xylem formation, of phloem formation and collapse, of rifts and stresses in bark, or seasons of activity of roots. Important contributions on these subjects have been made recently by L. Knudson, ${ }^{2}$ H. P. Brown, ${ }^{3}$ and I. W. Bailey. ${ }^{4}$

It was thought advisable, however, to make some measurements of the changes in length and thickness of leaders and young stems and this was done both in the early part of the season and in the autumn.

\footnotetext{
${ }^{1}$ Shreve, Forrest. Stem analysis and elongation of shoots in the Monterey pine. Carnegie Inst. Wash. Year Book for 1919, pp. 88 and 89.

2 Knudson, L. Observations on the inception, season, and duration of cambium development in the American larch (Larix laricina Du Roi Koch). Bull. Torr. Bot. Club, 40:271-293, June 1913.

${ }^{3}$ Brown, H. P. Growth studies in forest trees. I. Pinus rigida Mill. Bot. Gaz., 54:386-402, 1912. II. Pinus strobus L. same journal, 59: 198-240, 1915.

- Bailey, I. W. Phenomena of cell-division in the cambium of arborescent gymnojpermas and their cytological significance. Proc. Nat. Acad. Sci., 5: 283-285, 1919.

- The cambium and its derivative tissues. II. Size variations of cambium initials in gymnosperms and angiosperms. Amer. Jour. Bot., 7:355-367, 1920. III. A reconnaissance of cytological phenomena. Amer. Jour. Bot., 7:417-434, 1920.
} 
The daily procedure in elongation during September may well be illustrated by the following excerpts from the notes:

The temperature of the air varied between $13^{\circ}$ and $22^{\circ} \mathrm{C}$. during the greater part of the time, this equable feature of the climate being accompanied by fogs and high humidity.

The record of the first day was made on a 24-hour clock cylinder to give opportunity for minute analysis. This showed that the stem contracted as much as $0.3 \mathrm{~mm}$. in the forenoon period, which in this case was clear and sunny, and in the periods ending the next morning an increase of $12 \mathrm{~mm}$., or a net total of $8 \mathrm{~mm}$., was made. This behavior was duplicated in the following 10 days, during which time the period of elongation of the stem came to a close. Greater activity being displayed by the laterals, attachment was transferred to one of these and a similar procedure was recorded for 7 days, at which time it also came to a state approaching quiescence on September 8.

On October 15 the instrument was attached to the lateral of another plant continuously in the shade and the record for the succeeding 20 days shows daily variation, including shortening at midday, but with little total growth except on days on which the tempera ture of a large trunk rose to $17^{\circ}$ or $18^{\circ} \mathrm{C}$., or the air was humid by the effect of fog or rain. Such a case was produced by fog on October 21 and 22, which were followed by a period of a week of clear days with trunk and air temperatures not widely different in a range from $15^{\circ}$ to $22^{\circ} \mathrm{C}$. during which time the daily variations did not result in any actual increase.

The influence of humidity and water supply is illustrated still more strikingly by the behavior of No. 5 , an unbranched plantlet $40 \mathrm{~cm}$. high, probably about 16 months old. Attachment was made to the tip of this plant on September 8 and on the two succeeding days a midday decrease and a following larger. increase of $0.5 \mathrm{~mm}$. or less were displayed. Beginning at midday on the 11 th, rain fell continuously for 50 hours and an enormous acceleration ensued. The temperature during this time was $19^{\circ}$ to $20^{\circ} \mathrm{C}$. The total increase during this two-day period was over $10 \mathrm{~mm}$., which was 5 or 6 times the previous rate, in cool, dry days and cooler nights. On the day following the rain the increase fell to $2.5 \mathrm{~mm}$., after which the daily program of elongation and shrinkage followed, with a net increase, however, of $2.5 \mathrm{~mm}$. in 13 days, the rate diminishing on September 28, at the end of this period, which probably soon passed into the condition already described for No. 3. This record illustrates markedly the accelerating effect of humidity on growth and suggests that warm rainy periods of even a few day's duration may have a permanent effect on the structure of the trunk.

These features are in accordance with a procedure which has been studied and described in great detail in a large number of morphological types of plants. Excessive or maximum water-loss during the daylight period lessens the rate and amount of enlargement in growing stems and causes fluctuations in volume of quiescent ones.

It is to be noted that the imbibitional conditions in stems a year old are much different from those of large trunks. Thus, in such a stem the epidermis is still unbroken, the cortex is chlorophyllose, over a millimeter in thickness, and the numerous long leaves, which still are present, may withdraw a large amount of water. The growing layer is nearly as thick as the cortex, while the central pith is 3 or $4 \mathrm{~mm}$. in diameter, the rays through the wood being much in evidence. One-third of the diameter of a stem $24 \mathrm{~mm}$. in thickness is thus made up of thin-walled cells in a high state of hydration and in a condition in which the water balance of the system may be quickly modified by evaporation or temperature changes. 
The measurements in the first series were made by bringing a modified auxograph lever in contact with the upright leader of a young pine which had been surrounded by a platform and held rigidly in position. The net gain of the daily fluctuations during the whole of August amounted to nearly a millimeter in thickness. Now ensued a period of high fogs which during 3 days equalized temperatures and humidity, reducing the daily variation, but resulting in no increase. Finally, on September 5, rising temperatures and humidity had the effect of producing a net gain which amounted to about 0.5 $\mathrm{mm}$. before a rain came disarranging the clock-work of the recording cylinder. Two days after this rain the instrument was again put in order and during the following 2 weeks a daily increase in diameter was recorded which, on September 27, had produced a net thickening of about $2 \mathrm{~mm}$. The registration was discontinued for 2 weeks, but was resumed on October 15. The increase had evidently continued during the interval, but was now coming down to a minimum, as the net thickening in the following 2 weeks, terminating October 29, was about $0.5 \mathrm{~mm}^{1}{ }^{2}$

Further observations on the variations of young stems were made in the autumn of 1920. A small tree, No. 8, 8 or 9 years old, about 3.5 meters in height, was bent over so that the terminal leader which had been formed by the growth beginning in February was held rigidly on a block of wood, in such manner that the vertical swinging alm of an auxograph might rest directly upon it. Another tree, No. 9, 5 years old, about 2.7 meters in height, was similarly arranged but with the internode formed during the previous year under measurement.

The record of No. 8 shows that enlargement in diameter had ceased on September 17 and that progressive shrinkage was recorded during the following 10 days. Irrigation was followed by some increase. The daily variation was not so great in the older internode of No. 9, and irrigation was followed by a more pronounced and long-continued enlargement.

The auxographs were again brought into bearing at the same places on the internodes of these two young trees for 10 days beginning February 24, 1921. The terminal internode of No. 8 was now nearly a year old and the buds at its tip had made an elongation to about 5 to $10 \mathrm{~cm}$. during the previous month. The internode of No. 9, upon which measurements were made, was now nearly 2 years old. The buds at the tip of the terminal internode above it had made an elongation of 3 to $5 \mathrm{~cm}$. It was soon seen that the two-year-old internode of No. 9 had not awakened, as the pen traced a straight line, the soil water supply being sufficient to maintain the water balance in the wood. The one-year-old leader of No. 8 was already in course of growth, and during the 10 days of the record showed an increase of $0.8 \mathrm{~mm}$. in thickness. A slight depression of the rate of growth occurred in the midday period, especially on days of highest temperature.

Passing from these measurements to variations in pine trunks, more complex conditions are encountered. In securing dendrographic

\footnotetext{
1 The records upon which the above statements are based were interpreted erroneously, as stated in my account of 1919. Sec Carnegie Inst. Wash. Year Book for 1919, p. 76.
} 
measurements the old, flaking outer cork layers of the bark were cut away and bearings were taken on the thin layer formed in the previous year, which had not yet become heavily browned. Internal to this is the bast, which forms a layer about $2 \mathrm{~mm}$. in thickness, and internal to this is the cambium layer. Growth or permanent enlargement would depend upon the division, enlargement, and differentiation of the elongated, spindle-formed elements of the cambium.

While new cells are being formed by division, and these are undergoing the enlargement constituting one of the main features of growth, these cells form a very thin layer external to the woody cylinder. This woody cylinder, with its closed systems of tracheids or woodcells, is the conducting system by which solutions pass from the roots to the transpiring surfaces of the leaves.

The rate of water-loss from the leafy surfaces may vary widely during the course of the day as a result of changing temperatures of the air, while the temperature at which water passes into the trunk at its base changes but slowly, and chiefly in response to soil-moisture proportions. It is obvious that such relations between absorption and loss of water may result in more water being given off during any period than is taken in. Such excessive transpiration can, of course, occur only from a balance or surplus, and this accumulated reserve, occupying the entire trunk of the tree, may be very great. Any lessening of its volume, however, would cause variations in the dimensions of the trunk to an extent determined by a set of conditions which need not be elaborated here.

The most valuable dendrographic data, so far available, are those obtained from the Monterey pine. The separate trees, five in number, to which dendrographs have been attached are briefly described as below:

No. 1 is about 25 meters in height, bearing only short, thin branches, with the trunk 40 to $44 \mathrm{~cm}$. in diameter a meter above the ground. Cores taken out by increment borers show 28 well-defined layers or "annual rings." The radial increment the first year was $14 \mathrm{~mm}$., and varied from 2 to $5 \mathrm{~mm}$. in the succeeding ten layers, which may not safely be taken to represent annual formations. The second series of ten layers has a total thickness of $62 \mathrm{~mm}$., the separate layers varying from 2 to $10 \mathrm{~mm}$., the thinner ones being in all probability formed as the result of autumnal rains, such as occurred in 1918. The total of the 11 outermost layers amounts to $60 \mathrm{~mm}$. of radial thickness, varying from 2 to $9 \mathrm{~mm}$. in the separate layers. Thus, on the basis of experience described below, by which the tree after having formed a layer $5 \mathrm{~mm}$. in thickness in the early part of 1920 was awakened to form a second layer of equal thickness by irrigation, it is assumed that the layer $2 \mathrm{~mm}$. thick interior to the layer of 1919 , which is $8 \mathrm{~mm}$. in thickness, resulted from a rainfall of 5 inches early in September 1918. Formation of a 
layer $3 \mathrm{~mm}$. in thickness had taken place during the first half of the season in that year. Of the 31 layers or rings of this tree, one was added by irrigation in 1920, one has the appearance of resulting from autumnal rains in 1918, one very thin one was probably formed under such circumstances in 1907, and another in 1904. The tree may therefore be considered as being 27 years old at the beginning of the season of 1921.

During 1920 a second instrument was placed on the trunk, 8 meters above the ground. Tree No. 2 of this species was about 18 meters in height and $40 \mathrm{~cm}$. in diameter near the base, with heavier branches than No. 1, and stood on a sandy slope facing northward. A wide variety of devices was tested on the instruments attached to this tree, so that no continuous record, such as that which has been obtained from No. 1, was obtained.

Monterey pine No. 6 was the smallest tree of this species to which the dendrograph with floating frame was applied. It was about 10 meters in height, $16 \mathrm{~cm}$. in diameter near the ground, and stood on a northfacing slope in position where the direct sunlight did not strike the ground, which therefore remained at a lower temperature and with a higher moisture content than the other trees. The presence of 20 rings or layers indicated an age of 17 years. The layer formed in 1920 had a thickness of $3 \mathrm{~mm}$., which was equivalent to that of 1919 , and the secondary layers of 1907 and 1904 were plainly apparent.

No. 7 was about 14 meters in height and $35 \mathrm{~cm}$. in diameter near the base. Observations on this tree were confined to dendrographic measurements of the woody cylinder from bearings made at the bottom of borings extending through the wood of the previous year. Temperatures of the outer layer of the trunk and of the heart were also taken by mercurial thermometers. This tree stood on a north-facing slope of a "fog channel" near No. 6, which was exposed to similar conditions.

The most obvious points of interest in the growth program of each year are those which concern the dates of awakening and cessation of growth of terminals and of the trunk.

Elongation of terminals of No. 1 began early in February 1919, but no enlargment of the trunk was measurable until March 30. A period of low relative humidity and high temperature resulted in no increase in diameter of the trunk between May 29 and June 6, after which enlargement took place at a low rate for a few days, alternating with periods in which only reversible variations were discernible. This later phase of growth might be identifiable with an after development of phloem, such as has been described by Brown ${ }^{1}$ in Pinus strobus. The total net accretion on the diameter measured by the den-

${ }^{1}$ Brown, H. P. Growth studies of forest trees. Bot. Gaz., 59:237. 1915. 
drograph was $9 \mathrm{~mm}$. and the thickness of this layer (laid down in 1919) taken from a boring on another diameter, in January 1921, was about $8 \mathrm{~mm}$.

Heavy rains beginning on November 26,1919 , were followed by an increase beginning on November 29, which continued until December 14. A similar slight increase following rain took place early in January and late in January.

The instrument was reset on February 9, 1920, and a second one reached by a scaffolding attached at a point 8 meters above it, both making a record in which the variations in diameter were amplified 8 times (see fig. 4). The circumference of the trunk at the upper instrument was $100 \mathrm{~cm}$. as compared with $130 \mathrm{~cm}$. at the lower one. The levers of both instruments were set to give an amplification of 8 times, so that it was possible to make direct comparisons of the action of the trunk in the two places. The bark in both cases was thinned so that the contacts were made on layers of cork not more than a millimeter in thickness. The bark at the base of the tree was heavy and was coming away in flakes, while that at the upper instrument had begun to show only shallow rifts and was not more than 3 or $4 \mathrm{~mm}$. thick at any place. Thermometers thrust under the bark on the north side of the trunk showed temperatures as low as $6^{\circ} \mathrm{C}$. on the date mentioned and as low as $8^{\circ} \mathrm{C}$. on March 30 .

Some enlargement of the same type followed rain March 18 to 22, but this was followed by a period of reversing variations, and not until April 7 did a continuing enlargement begin which showed an initial rate slightly greater than that at the uppermost instrument, which began on the same day (fig. 5).

As this manuscript is being completed, the records for the early part of 1921 are available. They show that the tips of the branches on young and old trees began to grow about mid-January, and that the enlargement of the upper part of the trunk of this tree showed enlargement on the 27th of January, 2 days earlier than any increase of the lower part of the trunk. Action in the two places was synchronous in 1920, but did not begin until 2 months later than the awakening of the tips of the branches. No attempt has yet been made to correlate these facts with the activities of the roots, but the observations of W. B. McDougall are to the effect that growth of the roots begins quite early in the season and that it depends largely upon moisture and temperature. ${ }^{1}$

As in the previous year, a period of reversible variations began late in May 1920, which continued until July 2, at which time the soil moisture content had come down to 5 to 7 per cent. The total accretion at the base of the tree was slightly less than $3 \mathrm{~mm}$., slightly

${ }^{1}$ McDougall, W. B. The growth of forest tree roots. Amer. Jour. Bot., 3:385-392. 1916. 


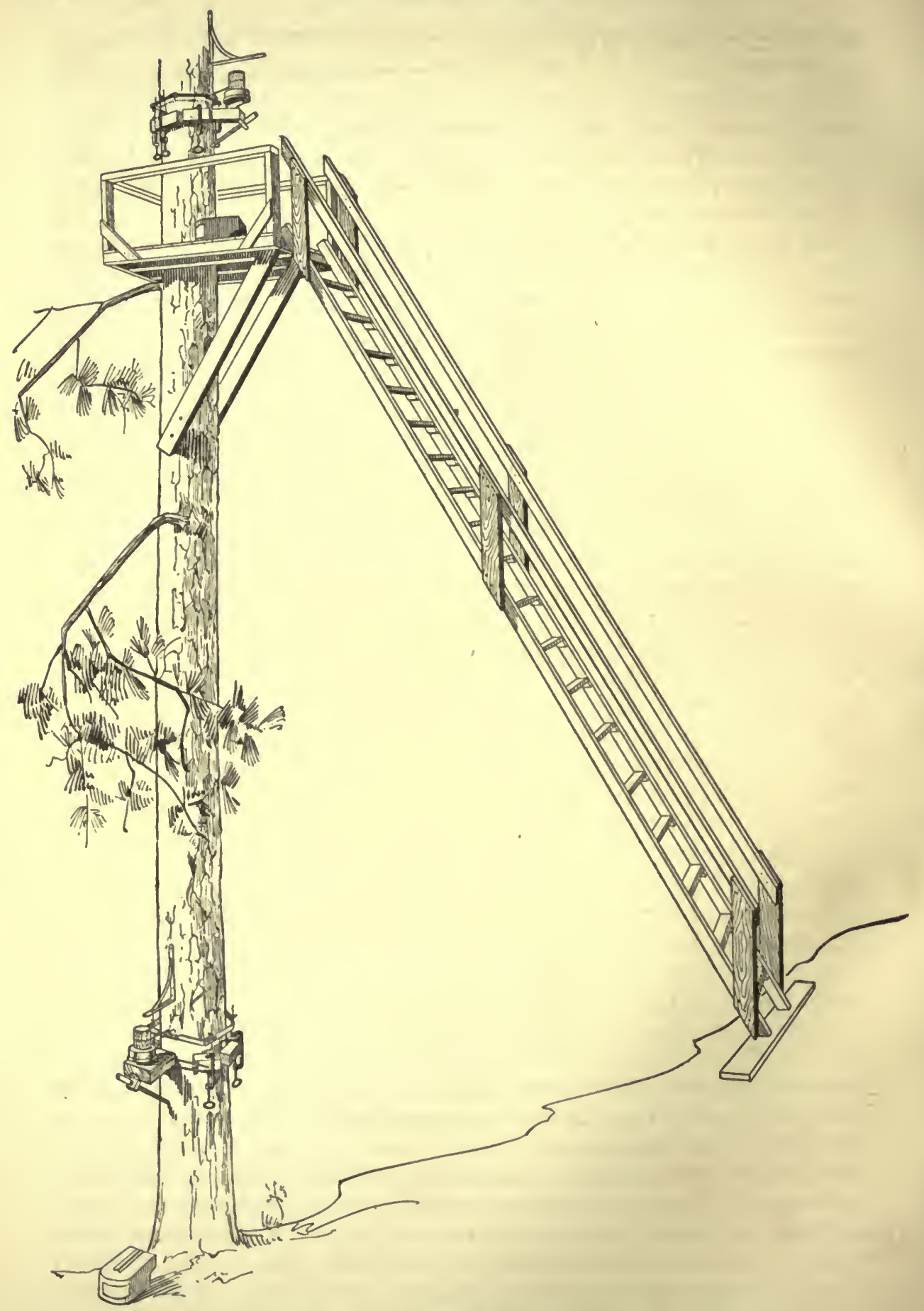

FIG. 4.-Monterey pine No. 1, with dendrographs attached near the ground and at a height of 9 meters. 
greater than $2 \mathrm{~mm}$. at the upper instrument, differences which might be seen in comparison of different diameters at any part of the trunk. This layer showed a thickness of $4 \mathrm{~mm}$. in the boring on a different radius, on the lower and upper part of the trunk.

A number of tile pipes were now sunk in the soil in an area around the tree, so that water might be conducted to the absorbing roots and 3,000 gallons of water were poured into these holes on July 1, 1920, with the result that an enlargement was visible a day later, which was slightly

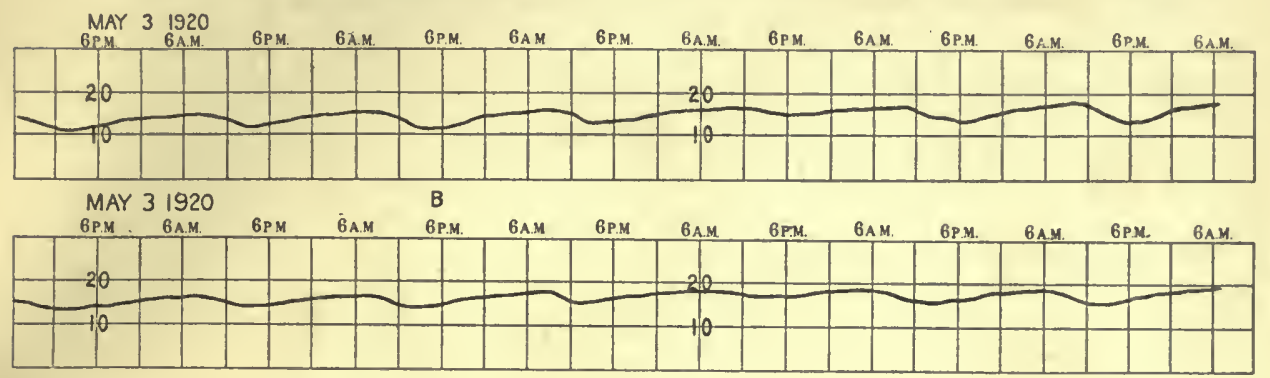

A

FIG. 5.-Dendrographic records of the changes in the trunk of a Monterey pine made by the two instruments attached to No. 1, as in fig. 4. Record $A$ is from the lower part of the trunk and $B$ from the higher point, for the week beginning May 3, 1920. The sheet is marked into 6-hour periods and the spaces represent $10 \mathrm{~mm}$., the actual changes in the trunk being $\times 8$. Enlargement and partially equalizing daily variations are displayed.

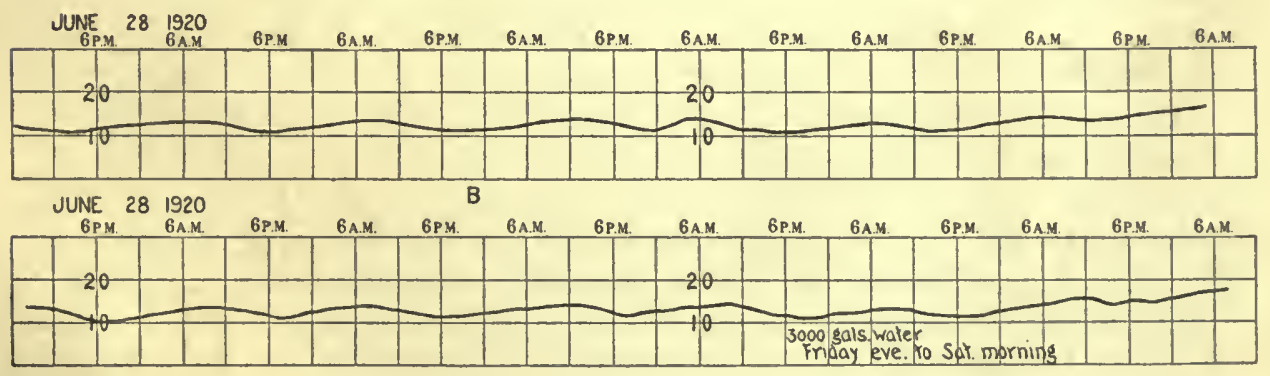

A

Frg. 6.-Equalizing daily variations of trunk of Monterey pine No. 1 for week beginning June 28,1920 . Application of water to soil around roots after $6 \mathrm{p}$. m. on July 2 was followed by upward course of record lines from both instruments. Variations $\times 8$ on $10 \mathrm{~mm}$. scale.

greater at the lower instrument (fig. 6). Additional water was given on each of the 2 days following, and enlargement continued at the upper instrument until about August 16. During this period of 16 days an enlargement of $2 \mathrm{~mm}$. in diameter had taken place at the upper instrument, 9 meters above the ground, and of $4 \mathrm{~mm}$. at the lower instrument, 1 meter above the ground (fig. 7). Enlargement at the base continued until September 15, at which time a further thickening of $2 \mathrm{~mm}$. had taken place, making a total thickening of $9 \mathrm{~mm}$. at the base. Both measurements were in agreement with borings taken in January and February 1921. Then followed a month of 
reversible variations with some slight increases on both places on the trunk following a rain on October 14. Again some increases occurred, beginning on November 16 . Similar period of increase occurred in December. No actual seasonal or winter shrinkages of the stem at either point could be detected.

Very interesting occurrences of this sort, however, were observed in connection with rains. On April 15-16, December 21-23, 30-31, a continuous enlargement of the trunk took place which would be wholly or almost wholly lost on the sunny day following.

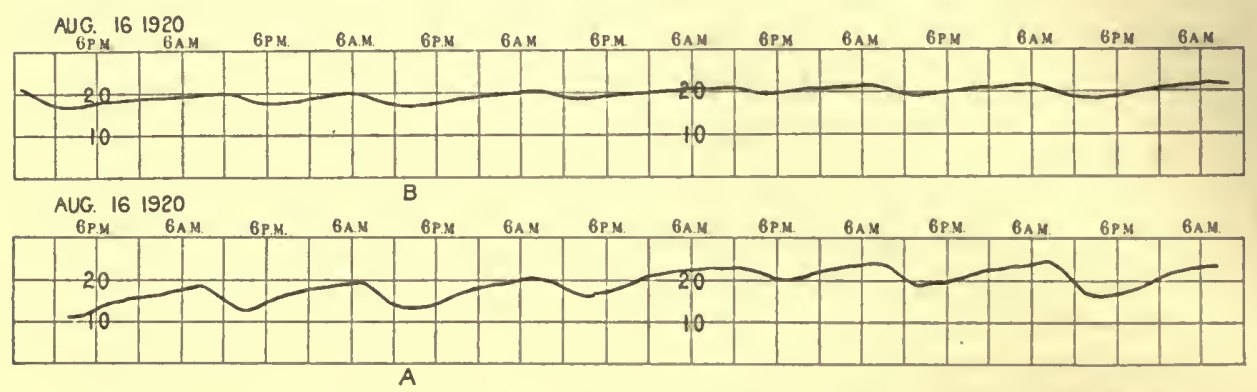

Fig. 7.-Dendrographic record of the variations of lower and upper parts of trunk of Monterey pine No. 1 at end of period affected by irrigation.

The present record is closed on January 27, 1921, at which time the staminate flowers were nearly mature and the terminal buds were beginning to swell, and some actual enlargement of the trunk had begun and was still in progress on January 31.

During 1920 the basal part of the trunk had shown a total enlargement of nearly $9 \mathrm{~mm}$. in diameter, and the section 8 meters from the ground about $6 \mathrm{~mm}$. The accretion of 1920 appeared in borings at the base of the tree as two layers in two cores 5 and $4 \mathrm{~mm}$. in thickness, when measured at the end of January 1921. The outer layer may be taken as representing accretion following irrigation, which, it may be suggested, may have been largely in the phloem. The borings at the higher point showed two layers, 4 and $2 \mathrm{~mm}$. in thickness.

Awakening of buds took place several weeks before enlargement of the trunk began in 1919 and 1920, but in 1921 growth of both kinds was apparent the last week in January, nearly two months earlier than the observed dates of enlargement of trunks in previous years.

The variations of a younger tree were sought by the attachment of an instrument to Monterey pine No. 6 on February 12, 1920. This tree may be identified as beginning in 1904, as it made a second layer of wood in its first year and shows the extra formations in 1907 and 1918. The floating frame of the instrument was of invar, the levers being set at first to amplify 5 and later to 15 times. The trunk had a diameter of $18 \mathrm{~cm}$. and the first discernible enlargement was on 
March 16, after which acceleration carried growth to a maximum rate in the last 10 days of April. The rate now slackened and growth ceased about June 1, with a total increase of $4.5 \mathrm{~mm}$. in diameter.

A rain on June 14 was followed by some growth in the following week, after a period of reversible alterations ensued. Not until late in July did a slight enlargement recur and a similar impulse was recorded at the end of August (fig. 8). No further increase could be detected, but a shrinkage began on October 11 which continued until
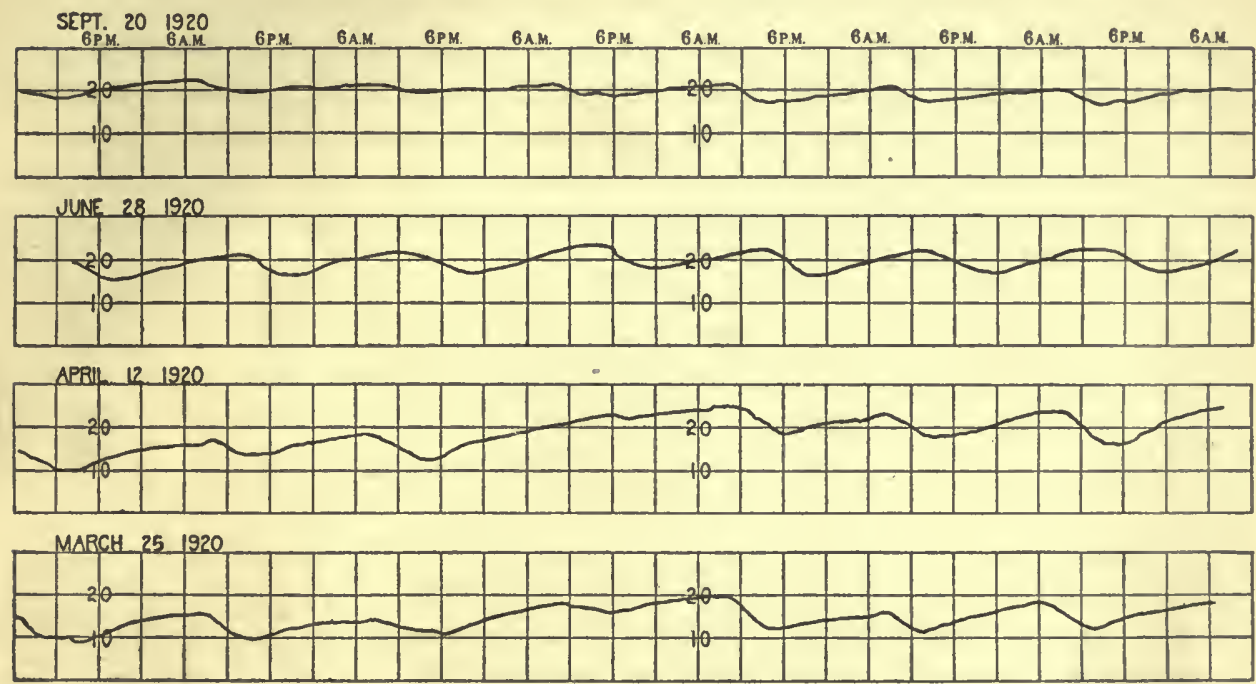

MABCH +1920

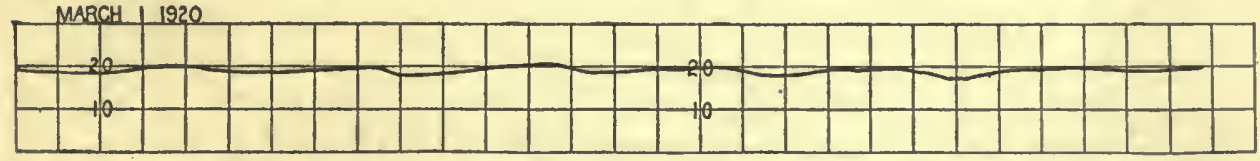

Frg. 8.-Dendrographic records of Monterey pine No. 6, with no growth in week of March 1, 1920, beginning growth in week of March 22-29, vigorous enlargement in week April 12-19 daily equalizing variations of wide amplitude in week of June 28-July 5, and reduced variations late in September. Variations $\times 5$ on scale of $10 \mathrm{~mm}$. intervals.

the instrument was dismounted a week later. A total increase of $5 \mathrm{~mm}$. had been recorded. It is to be noted that the terminals and tips of the branches had made a growth of several centimeters when the observations were begun, and that such elongation must have started about two months prior to the increase in the trunk.

Measurement of another pine (Pinus chihuahuana), on the slopes of the Santa Catalina mountains, an isolated range near the Desert Laboratory, gave a set of results under conditions different from those afforded by the indeterminate seasons of the coastal climate. A tree $40 \mathrm{~cm}$. in diameter, in the lower edge of the pine belt at about 2,000 meters, was selected for observation. This location is characterized by a coarse granitic soil, winter and mid-summer rainfall; minimum air temperatures of $8^{\circ} \mathrm{C}$. and summer maxima of $40^{\circ} \mathrm{C}$. are of record. 
This tree stood about 4 miles from the base of the mountain and the instrument was transported this distance by pack animals and put in action on April 4, 1918, being visited weekly until the end of October. The record showed some enlargement, beginning April 14, with a cambium temperature of $13^{\circ} \mathrm{C}$, with readings as high as $28^{\circ} \mathrm{C}$. in the following 10 days. When observations were taken on April 23, the temperature of the cambium was $10^{\circ} \mathrm{C}$. and enlargement had ceased. A slight swelling occurred May 13-20. On May 22 a shrinkage began
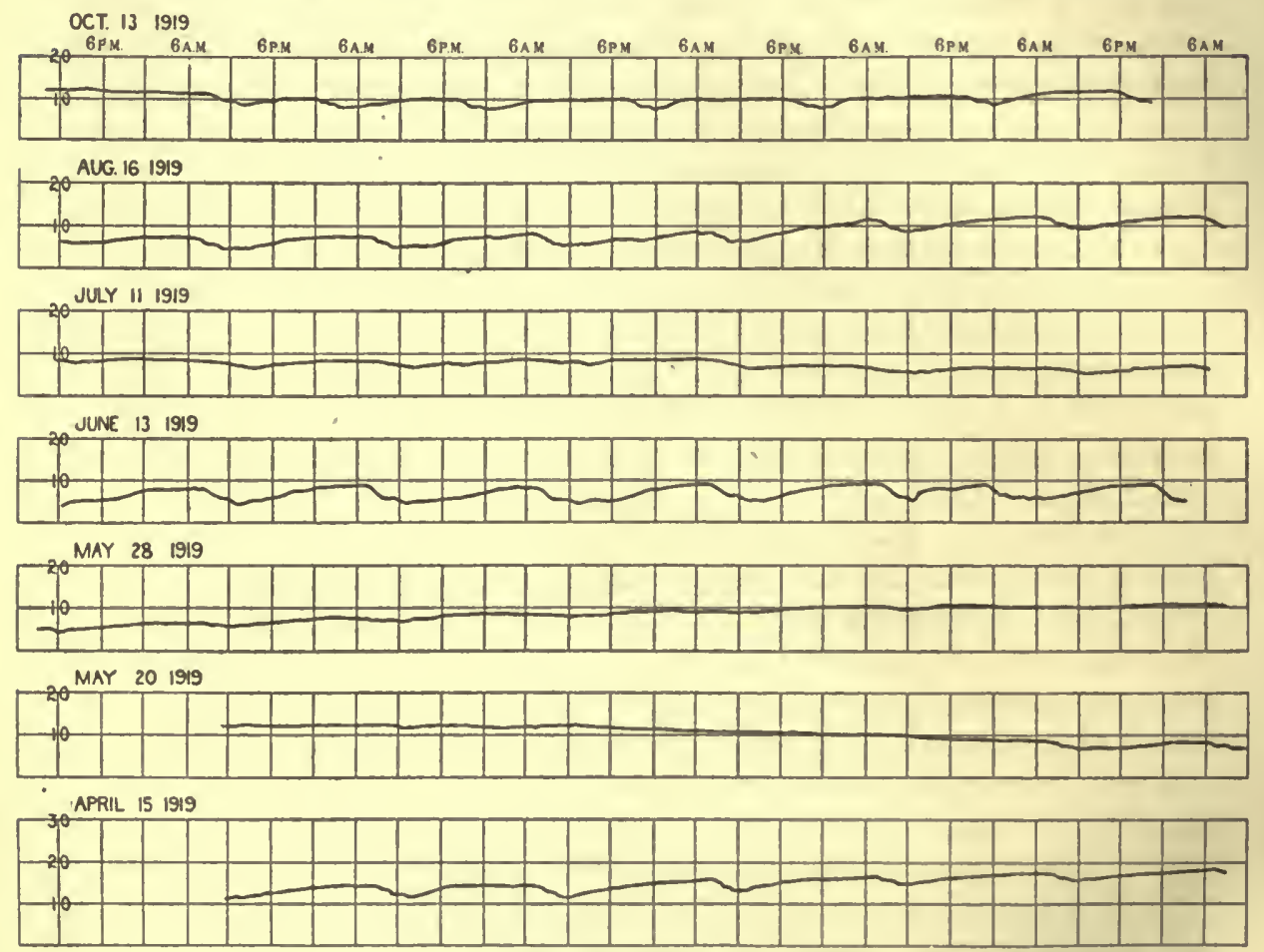

FIG. 9.-Dendrographic records of Chihuahua pine, with variations $\times 5$ on $10 \mathrm{~mm}$. intervals. Some enlargement shown in week beginning April 15, 1919; shrinkage during week beginning May 20; enlargement in week beginning May 28; daily equalizing variations of wide amplitude in week beginning June 13; reduced variations and shrinkage in week beginning July 11; incrensed variations and actual increases in diameter in week beginning August 16, and reduced daily variations in late October.

which in 6 days amounted to $1 \mathrm{~mm}$., or half the total increase during the previous two months. Increase began on May 28, which amounted to about $2 \mathrm{~mm}$. on June 14, at which time equalizing variations began at tree temperatures of $23^{\circ}$ to $27^{\circ} \mathrm{C}$., which continued until June 28. Now, in the extreme hot mid-summer, shrinkage began which continued until July 20 , or until about 3 weeks after the summer rains began. During this time a shrinkage of about $2 \mathrm{~mm}$. had ensued, which was equivalent to about three-fourths of the gain up to this date. A period of increase, ending August 23, resulted in a gain of 
$5 \mathrm{~mm}$., of which nearly one-half was lost in the last week of August. Another slight swelling began September 14, terminating October 5, after which equalizing daily variations occurred until the instrument was dismounted October $22^{1}$ (fig. 9).

The total enlargements amounted to about $10 \mathrm{~mm}$. and the total shrinkage during the season to about $5 \mathrm{~mm}$. It is obvious that the woody layers formed in such an interrupted cycle of growth must be difficult of interpretation by the observers who seek to obtain the history of the tree from its "annual rings." Dr. Shreve has found that individuals of this species form two such rings in locations at slightly greater altitude but similar climatic conditions. ${ }^{2}$

A dendrograph was attached to a yellow-pine tree (Pinus scopulorum) at the Fort Valley Forest Experiment Station near Flagstaff, Arizona, late in April 1920. This tree was about $45 \mathrm{~cm}$. in diameter and had apparently ceased growth or was quiescent during this season. No permanent change in diameter amounting to as much as a millimeter occurred during the summer. Equalizing variations were marked, however, during the latter half of July, after which the record showed but little variation. Mr. G. A. Pearson, in charge of the Experiment Station, reports that this tree showed some growth of branches and terminals in $1921 .^{3}$

A dendrograph was installed on the basal section of a yellow pine (Pinus ponderosa) at the Alpine Laboratory, which made a record from June 5 to September 15, 1920. Mr. Loftfield, who was in charge of the instrument, reports that this tree was nearly $36 \mathrm{~cm}$. in diameter and that it stood on an east-southeast slope near the Douglas fir which was also measured. Thermographic and hygrographic records were obtained which pertain to both trees. As the instrument was set to amplify 15 times, the daily equalizing variations appeared very marked at the beginning, amounting to as much as $0.5 \mathrm{~mm}$. in diameter daily. An increase in diameter was noticeable on June 14, on which date an inch of rainfall was noted, but this was only a temporary increase, as equalization followed. A week later the buds awoke and disturbances of the daily variation ensued. The branches reached full length early in July and the leaves full size by the middle of the month, but not until a month later (August 12), in a period of heavy rains, did an increase take place. This continued until September 4, and during this period of 23 days a net enlargement of nearly $2 \mathrm{~mm}$. in diameter had taken place, after which some shrinkage accompanied the daily

\footnotetext{
1 The above statements are to be taken in eorrection of the preliminary notice on the growth of the Chihuahua pine in Carnegie Inst. Wash. Year Book for 1918, p. 75.

${ }^{2}$ Shreve, F. The density of stand and rate of growth of Arizona yellow pine as influenced by climatic conditions. Jour. Forestry, 15:695-707. Oct. 1917.

${ }^{3}$ Pearson, G. A. The relation between spring precipitation and height-growth of western yellow pine saplings in Arizona. Jour. Forestry, 16: 677-689. 1918. Boerker, R. H. Relation between height-growth of lareh seedlings and weather conditions. Jour. Forestry, 16:861870. Dec. 1918.
} 
variations. The effects of humidity and temperature will be presented in a later section. A core, taken from this tree by Dr. A. E. Douglass, showed 74 layers or rings which varied from 1 to $5 \mathrm{~mm}$. in thickness, that for 1918 and for 1919 being about the same thickness as the measurement for 1920 just given.

\section{MEASUREMENTS OF A SPRUCE AND A FIR.}

The Douglas fir (Pseudotsuga taxifolia), at the Alpine Laboratory on the slopes of Pikes Peak to which the dendrograph was attached, was nearly $36 \mathrm{~cm}$. in diameter and the instrument had an amplification of nearly 16 times. The buds were developing rapidly when observations were begun on June 17 , at which time increase of the diameter of the trunk was visible in the daily variations. Growth was already in progress. The increase continued at a low rate until July 21, at which time a total gain of $2 \mathrm{~mm}$. in diameter had been made. After some days of equalizing variations, with temporary swellings consequent upon rains, an increase began August 11 , which continued until the $22 \mathrm{~d}$, making the total accretion for the season $2.6 \mathrm{~mm}$. The shrinkage which ensued during the first half of September reduced this total to $2 \mathrm{~mm}$.

The only continuous record of the growth of this tree which had been made previously is that by Mr. A. Mallock, who measured variations in the girth of a tree which had a circumference of $331 / 4$ inches, by means of an invar tape connected with glass prisms arranged to observe movements of interference bands. These observations were made July 5 to July 16, 1917, in England. It is not known whether any growth had taken place earlier in the season, but a shrinkage was in progress during the first 3 days of the observations, after which enlargement began, and continued at a varying rate during the next 8 days. Slackening in the rate of growth occurred during the midday period, and the increase was most rapid at night and following rains. ${ }^{1}$

The actual beginning of growth of the trunk was not observed, but probably not much had taken place before the record began, as the buds were just opening. The record of this fir is to be compared with that of a blue spruce (Picea pungens), which was measured by an instrument in the hands of Mr. C. F. Korstian. This tree is on the Cottonwood nursery grounds, 25 miles southeast of Salt Lake City, at an elevation of about 2,250 meters. This tree was $38 \mathrm{~cm}$. in diameter and enlargement was in progress and the buds were opening on June 7. The course of growth was similar to that of the Douglas fir, and as it is being described in an article by Mr. Korstian, in the Botanical Gazette for June 1921, it will not be repeated here.

${ }^{1}$ Mallock, A. Growth of trees, with a note on interference bands formed by rays at small angles. Proc. Roy. Soc., 96 B (see especially p. 193), 1919. 


\section{GROWTH OF THE CALIFORNIA LIVE OAK.}

The California live oak (Quercus agrifolia), which is one of the eommonest of the oaks of the Pacific slope and in the region of the Coastal Laboratory, is a small tree with trunks 25 to $50 \mathrm{~cm}$. in diameter. The leaves of one season remain on the tree until those of the next season are unfolding, which in this region begins early in February. The first indication of awakening activity is the elongation of the leafy branches which may occur in some individuals 2 or 3 weeks earlier than in others a short distance away. As will be seen from the records discussed below, enlargement of the trunk began in March, somewhat earlier than in the Monterey pine in the same locality.

Measurement of this species includes one feature widely different from the pines, in that the bark remains alive and turgid until it reaches a thickness as much as $5 \mathrm{~cm}$., and it is upon the surface of this structure that dendrographic bearings must be taken. The bark finally becomes deeply and irregularly furrowed, so that any single line around a tree may cross not more than three or four of such rifts, which appear to go nearly to the wood, a condition which was found in the first tree measured.

A dendrograph with a floating frame of bario in the shape of a large $\mathrm{U}$ was mounted on a rectangular frame support and put in place on No. 1 of this tree on February 17, 1919. On March 1 a slight increase was recorded, but not until March 11 did positive growth begin and this continued until the end of May. Temperatures $(1 \mathrm{~cm}$. interior to the surface of the bark) of $7^{\circ}$ to $9^{\circ} \mathrm{C}$. were recorded during February and March, rising to $14^{\circ} \mathrm{C}$. during the growing period. Later in the summer records of $18^{\circ} \mathrm{C}$. were taken.

Continuous records were kept and on February 10, 1920, the instrument was changed to one using a belt of blocks as a support for the floating frame of bario. No growth of the tips of the branches had yet taken place and temperatures as low as $6^{\circ} \mathrm{C}$. were noted on several mornings. One record of $9^{\circ} \mathrm{C}$. was taken as late as March 30 in the growing season.

The daily variations in this type of tree are very slight, so that the record did not vary widely from a level line until March 10, when it began to take an upward course which was not slackened until after May 5. Growth was again actively in progress by the 18th, to slow down again by the $28 \mathrm{th}$, a shrinkage of marked character taking place during the following week, followed by quiescence.

Growth was resumed on June 18, but soon ceased. Another impulse between June 22-28, another September 25-28, were observable. A decided shrinkage began on September 30, which continued for 7 days. An increase took place during the last 10 days in October, and a very marked shrinkage began December 1, which continued, with some 
interruptions, until about January 18, 1920. The total accretions amounted to about $5 \mathrm{~mm}$. in diameter, of which some was lost by the shrinkage described. ${ }^{1}$

Changes in size consequent upon rains followed until the instrument was replaced on February 9, 1920, by a model using the belts of blocks for a base, but retaining the U-shaped floating frame of bario. New shoots 5 to $8 \mathrm{~cm}$. long and leaves one-third full size were noted on March 15, but no enlargement of the trunk had yet occurred. Actual enlargement did not begin until April 9, one month later than in the previous year.

The instrument was jammed for 2 weeks, but when set in order showed continued action, justifying an estimate of the accretion not recorded. Growth at a decreasing rate continued until August 1, at which time a total increase of $4.6 \mathrm{~mm}$. had ensued. After this time the record varied but little from a level line and the instrument was dismounted on September 24, 1920, the record being continuous since February 24, 1919, a period of 19 months and including two entire seasons.

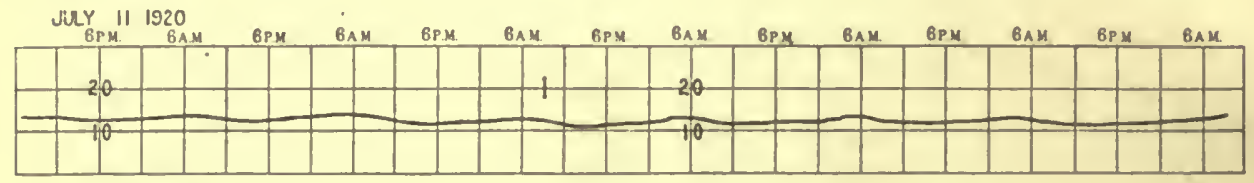

MAY $31 \quad 1920$

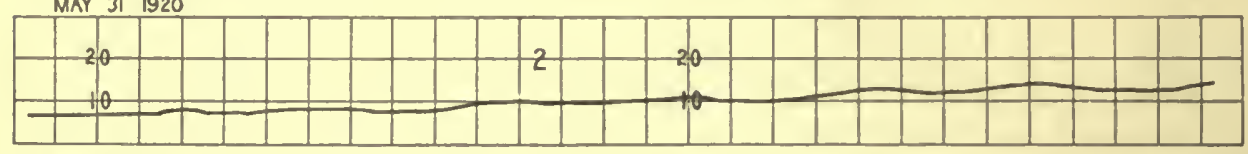

MARCH 151920

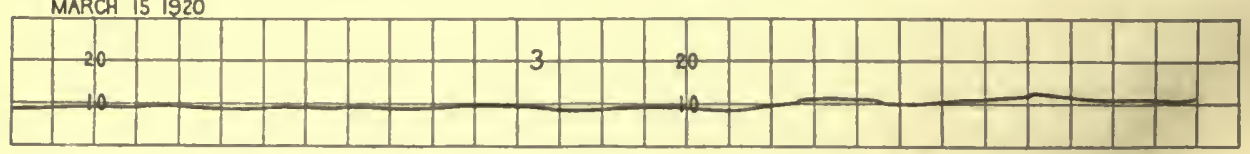

Fro. 10.-Dendrographic records of California live oak (Quercus agrifolia) No. 2. Beginning growth, denoted by upward course of the tracing, is shown in the week beginning March 15, 1920, and vigorous growth in week beginning May 31. Quiescence with small daily variations are seen in week beginning July 11 . Variations are $X 15$ on a scale of $10 \mathrm{~mm}$. intervals.

The measurements of a second oak were taken for 1920 by an instrument in which the floating frame was make up of three bars of invar and one bar of bario. The bark was intact and turgid, the trunk having a circumference of $54 \mathrm{~cm}$. at the place of mersurement, 1.3 meters above the ground. The levers were set to amplify 16 times and a thermometer was set in the bark to take temperatures of the north side at about a centimeter below the surface. No growth was to be seen in the tips of the branches of this tree on February 11, 1920,

\footnotetext{
1 The above statements are in part corrections of the preliminary report on this tree: The growth of an oak trunk. Carnegie Inst. Wash. Year Book for 1919, see p. 77.
} 
although others in more exposed localities had made elongations of 2 to $4 \mathrm{~cm}$. of the leafy shoots. A temperature of $8^{\circ} \mathrm{C}$. was taken on March 30, and not until April 1 was an upward movement of the pen to be seen, the record for the previous 6 weeks being a level line with but little daily variation.

Steady and continuous enlargement of the trunk continued until June 20. After a period of quiescence, enlargement again began on July 3, continuing until July 25. A total increase of $4.5 \mathrm{~mm}$. in diameter had taken place (fig. 10).

After a period of quiescence, with no indication of further seasonal enlargement, five drain tiles, $75 \mathrm{~cm}$. long, were set vertically in the loose sandy soil around the tree within a radius of 2 meters from the trunk, and water was turned into these openings so that 2,000 gallons were taken in without overflow between $5^{\mathrm{h}} 30^{\mathrm{m}} \mathrm{p}$. m. of August 1 and
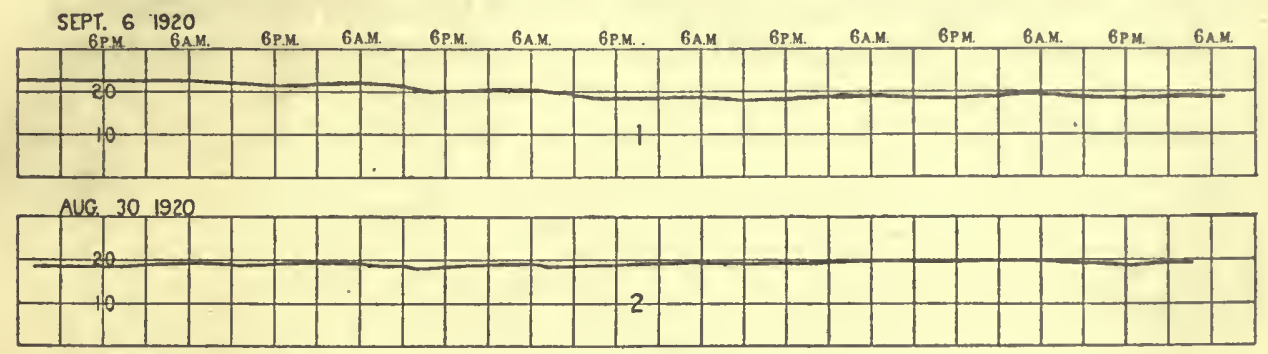

Auc 23,1920
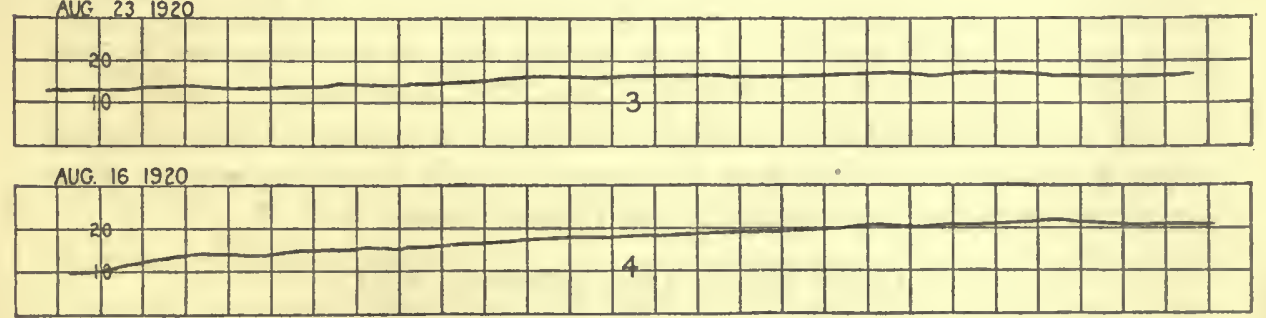

Fig. 11.-Dendrographic records of California live oak No. 2 illustrated in fig. 10 . A condition of quiescence had been reached when irrigation was begun before $6 \mathrm{p}$. m. on August 16, with a quick response in increase in diameter which continued through the week and until the middle of the following week, as shown in the record in the middle of the figure. Quiescence with but little daily variation is indicated in the record of the week beginning August 30. Some shrinkage ensued in the week beginning September 6,1920. Variations are $\times 15$ on a scale with $10 \mathrm{~mm}$. intervals.

$7^{\mathrm{h}} 30^{\mathrm{m}}$ a. $\mathrm{m}$. the next morning, and 1,000 gallons were added on the second night. The soil previous to irrigation had become so dry that it had a moisture content of less than 6 per cent. The consequences of the irrigation were extremely startling. Within 2 hours an enlargement was recorded by the dendrograph, which continued so that during this week an actual increase of about $0.5 \mathrm{~mm}$. had taken place in the diameter of the trunk, including the bark. The rate soon slackened, however, and no growth was visible on August 27, at which time a total accretion of $1 \mathrm{~mm}$. had been made to the diameter (fig. 11). 
The experiment was repeated by giving the soil around the tree 2,000 gallons at $9 \mathrm{p}$. m. on September 15. Again a swelling was noticeable within 4 hours after the water was laid on, and not more than 800 gallons had been given the soil. Enlargement continued for 3 days, with a total addition of $0.3 \mathrm{~mm}$. to the thickness of the trunk. In the ensuing quiescent period no shrinkage occurred, and no swelling resulted from the rains of October 6 and 8. The instrumert was now dismounted.

The readiness of reaction of the live oak to increased soil-water supply and the shorter period of enlargement and small relative total are in contrast with the reactions of the pine growing in similar soil a few meters distant. The root system has been described by Cannon as including a well-developed superficial portion consisting of numerous short, slender roots which lie within a meter of the surface. ${ }^{1}$ The method of irrigation was calculated to wet the absorbing surfaces of these roots The actual path to be traversed from the absorbing surfaces

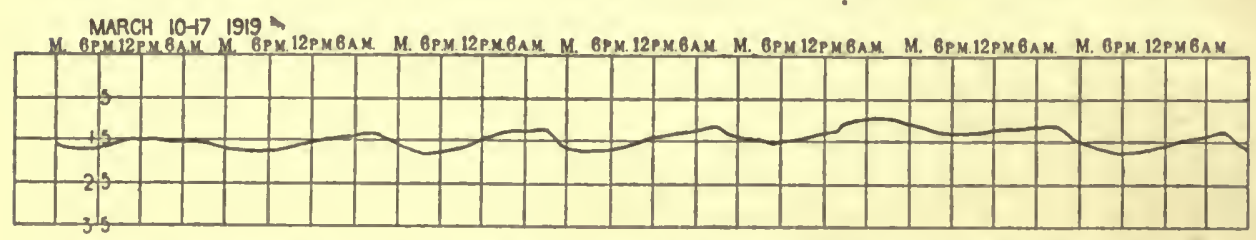

Fro. 12.-Dendrographio record of growth and variations in Arizona agh (Fraxinu"arizonica) for the week beginning March 10, 1910. Temperature of cambium region ranged from $6^{\circ}$ to $24^{\circ} \mathrm{C}$ A period of temperatures from $6^{\circ}$ to $9^{\circ} \mathrm{C}$. on the 16 th and 16 th was characterized by littlo. shrinkage. Variations are $\times 10$ on a scale of $10 \mathrm{~mm}$. intervals.

to the part of the trunk in which swelling was measured was not less than 2 meters, and this was traversed by the water supply in such quantity as to be measurable in less than 4 hours.

\section{GROWTH OF THE ARIZONA ASH.}

The Arizona ash (Fraxinus arizonica), a rapidly growing species which forms a trunk 25 to $50 \mathrm{~cm}$. in diameter, occurs along streamways in Arizona and New Mexico. It is planted around dwellings and the size attained appears to bear a direct relation to the available water supply.

A dendrograph, with a floating frame of bario having two bearing points opposite the lever, was attached to a tree near the residence of Dr. H. W. Fenner, in Tucson, Arizona, on March 8, 1919, and a thermometer was thrust under the bark. The instrument was set to amplify the variations ten times in the record. The trunk was almost exactly 1 meter in circumference and was compressed in one diameter. Irrigation practice had begun for the season and the

\footnotetext{
${ }^{1}$ Cannon, W. A. Tree distribution in central California. Pop. Sci. Monthly, 85:417:424. Nov. 1914. See pp. 420-421 and fig. 3 .
} 
ground was already saturated about the tree. The flower buds were beginning to move, but were not so far advanced as some that were seen on unirrigated land in the vicinity. The conditions were, in fact, as if the plant were growing along a water-course in its natural habitat (fig. 12).

Enlargement began on March 10 and continued at such rate that an enlargement of $4 \mathrm{~mm}$. had taken place by April 7, a period of 28 days (fig. 13). A period of depression and shrinkage, for 5 days during a cold storm, was followed by a resumption of growth which continued until August 25. Another period of depression ensued, but 6 days afterwards enlargement was again noticeable which lasted for a week, and other such impulses were displayed in September and

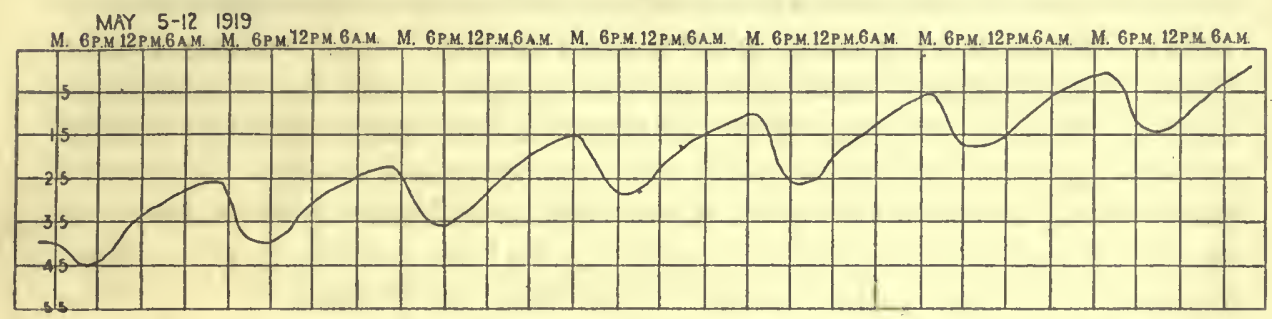

Fra. 13.-Dendrographic record of growth for the week beginning May 5, 1919, at a time when the daily variations were at a maximum. Relative humidity was low and transpiration was higb during the midday period, at which time great shrinkage took place. Variations $X 10$ on a scale of $10 \mathrm{~mm}$.

OCT. $13-201919$

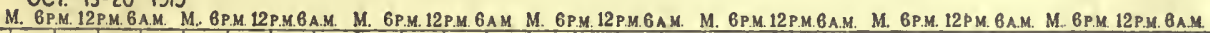

\begin{tabular}{|l|l|l|l|l|l|l|l|l|l|l|l|l|l|l|l|l|l|l|l|l|l|l|l|l|l|l|}
\hline \hline 5 & & & & & & & & & & & & & & & & & & & & & & & & & & \\
\hline \\
\hline
\end{tabular}

Fro. 14.-Variations in Arizona ash during a final period of slow enlargement near the close of the season, October 13 to 20,1919 . Variations $X 10$ on a scale of $10 \mathrm{~mm}$. intervals.

October (fig. 14); after this equalizing variations of diminishing amplitude only were seen until leaf-fall occurred about November 17 to 24 , after which the record was nearly a level line until January.

The total increase in the diameter of the tree during the season amounted to about $26 \mathrm{~mm}$, and a core taken from the trunk below the bearings on April 20,1921, showed a layer of $12 \mathrm{~mm}$.

This instrument was replaced by a new setting on January 10, 1920, with an amplification of 5 times, and the record was a continued level line until April, when some equalizing daily variations began which were the only changes until June 10. An enlargement now began which continued until about July 20 with a depression of the rate in the last week in June, which may be coupled with the high temperatures and insufficient water supply of that period. Then followed only 
equalizing variations, which decreased in amplitude with the advance of the season, until the record was but little away from a level line until January 1921, when the instrument was dismounted to be replaced by one of improved pattern. The total increase during 1920 amounted to $12 \mathrm{~mm}$., or about one-half that of the previous year. The reduction of the measurements given was in fair agreement with measurements of cores taken from the tree in February 1921. The wood formed at the beginning of the season is characterized by extremely large vessels, which serve to denote the part of the layer formed earliest in the spring. ${ }^{1}$

Vines has described the annual rings of Fraxinus excelsior as being 2 to $3 \mathrm{~mm}$. in thickness and as consisting of an internal spring zone of wide vessels with wood-parenchyma and rather thin-walled woody fibers, external to which, later in the season, thick-walled woody fibers form with scattered, smaller vessels surrounded by wood parenchyma. The wood formed at the close of the season consists chiefly of wood parenchyma and small, very thick-walled vessels. He notes that young trees of this species in a damp soil may form a layer of wood $15 \mathrm{~mm}$. in thickness in a season, which is practically equivalent to that of the Arizona ash under conditions of irrigation. ${ }^{2}$

The daily variation in 1919 was greater than that seen at any other time or in any other tree. Thus the daily shrinkage in March might be as much as $0.4 \mathrm{~mm}$., with an over-compensating increase of $0.6 \mathrm{~mm}$. by the following morning; in April these measurements were $1.1 \mathrm{~mm}$. and $1.4 \mathrm{~mm}$. In May the variations rose to 1.6 and $2.1 \mathrm{~mm}$. Correlated variations are displayed by elongating seedlings of the ash during the same months.

The materials of which the floating frames were constructed were tested to determine whether or not some of this apparent variation might be due to shortening and lengthening of the metal bars and rods under changing temperatures.

Calibrations of a bar of bario, such as was used in this instrument, showed that its variation was 0.0000065 per unit part with $1^{\circ} \mathrm{C}$. The length of the axis of the yoke was 14.5 inches or $363 \mathrm{~mm}$., and its variation would therefore be $0.000025 \mathrm{~mm}$. for $1^{\circ}$, and $0.0005 \mathrm{~mm}$. for $20^{\circ}$, which would represent the possible total in any one day. This amplified 10 times by the levers would amount to about $1 / 200$ of one space on the record sheet. This would be wholly compensated by the expansion and contraction of the short contact screws and by the variation in the instrument, so that for the purposes of this research the instrumental error may be neglected.

1 The above calculations are to be used in correction of the statements in the Carnegie Inst. Wash. Year Book for 1919, p. 74.

Vines, 8. H. Text Book of Botany, p. 198. 1895. 


\section{GROWTH OF A BEECH TREE.}

An instrument with a floating frame of bario of the U-form was put in place on a beech tree (Fagus grandifolia) on the grounds of Johns Hopkins University at Baltimore on April 16, 1919, about the time development of the leaves was beginning. In addition to the somewhat irregular daily variations swellings were seen as a consequence of rains with subsequent shrinkage. Not until May 18, when the tree was in full leafage, did some increase show in the record. This continued until May 30, after which equalizing variations ensued, which continued until mid-July. A week of rains was followed by enlargements which continued for a month and had a net total of about half that of the spring growth in May and June.

Now followed a period of regular equalizing daily variations, which terminated about September 14. The ensuing enlargement, which lasted for 3 weeks, showed a total increase less than in the preceding active period. Only equalizing variations were now seen and the instrument was dismounted early in October. The total accretion to the diameter amounted to about $4.5 \mathrm{~mm}$. (fig. 15).

\section{EQUALIZING DAILY VARIATIONS IN DIAMETER.}

The equalizing changes in the trunk are such that the diameter is least at midday or in the afternoon, when the temperature of the trunk is highest. The difference between the readings of a thermometer thrust under the bark in early morning and at noontime is never more than $8^{\circ} \mathrm{C}$. or at most $10^{\circ} \mathrm{C}$, while that in the center of the trunk may be no more than a degree or two. Whatever the temperature might be, a rise would tend to expand the woody column. Dendrographic and other measurements show a decrease at this time. The trunk is seen to shrink at a time when the temperature is highest. It is obvious, therefore, that we must look to causes other than a direct temperature effect.

The first possibility to be tested was that of the water relations of the bark, and Monterey pine No. 7 was chosen for this purpose. A small section of bark and bast was removed from the north side of the tree below the instrument, and these two formations were separated and placed under the auxographs in the dark room in which swelling liquids now stood at $12^{\circ} \mathrm{C}$. The results are as below:

\begin{tabular}{|c|c|c|}
\hline Constituents. & Bast. & Cork. \\
\hline 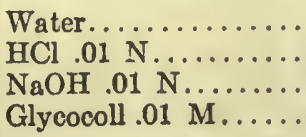 & $\begin{array}{l}12.5 \text { p.ct. } \\
5 \\
7.5 \\
10\end{array}$ & $\begin{array}{l}0 \text { p.ct. } \\
20 \\
15 \\
10\end{array}$ \\
\hline
\end{tabular}


The bast layer measured about $2 \mathrm{~mm}$. in thickness throughout and seemed fairly moist. The cork layer measured was light in color, presumably had been formed during the current season, and varied from 0.8 to $1 \mathrm{~mm}$. in thickness. It was easily separable from the older darker layers outside of it. The swelling of the bast was complete in 2 hours in the acid, 4 hours in the alkali, and about 7 or 8 hours in the glycocoll, while increase in water continued for nearly a day. The swelling of the new cork in the acid went on at a very slow rate for about 2 days, while it continued for 5 days in the alkali. It was complete in the glycocoll solution in about 10 or 12 hours.
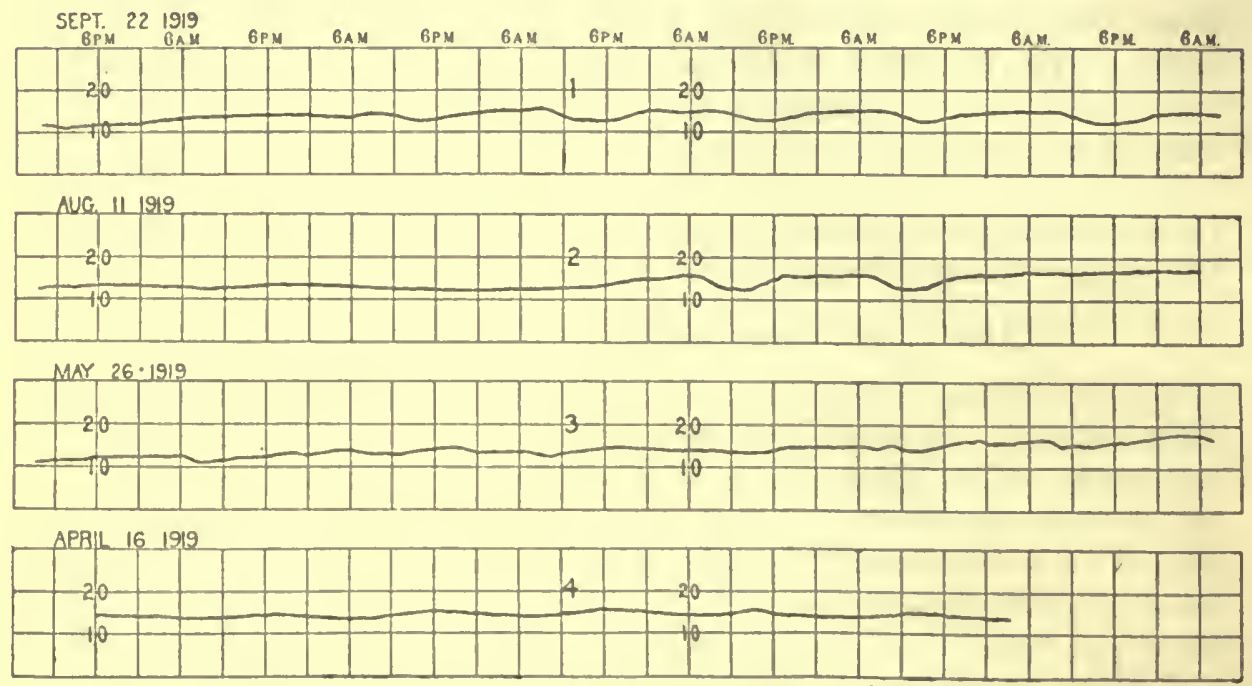

Fro. 15.-Dendrographic records of American beech (Fagus orandifolia), showing only slight daily variations in April, increases beginning late in May and continuing until September.

Separate samples of cork and bast were taken from another place on the trunk and sections were tested with the auxograph to ascertain the water deficit of these tissues after a week in which growth had come to a standstill, presumably on account of the dry, hot days. These sections were swelled at $12^{\circ} \mathrm{C}$. and the results are as below:

\begin{tabular}{|c|c|c|}
\hline Solutions. & Bast. & Cork. \\
\hline $\begin{array}{l}\text { Water.............. } \\
\mathrm{HCl} .01 \mathrm{~N} \ldots \ldots \ldots \\
\mathrm{NaOH} .01 \mathrm{~N} \ldots \ldots \ldots \\
\text { Glycocoll } .01 \mathrm{M} . \ldots .\end{array}$ & $\begin{array}{l}7.5 \text { p. ct. } \\
10 \\
22 \\
15\end{array}$ & $\begin{array}{l}6 \text { p.ct } \\
9 \\
10 \\
20\end{array}$ \\
\hline
\end{tabular}


These swellings were concluded at the end of 3 days, the course of enlargement being much as has been previously described. The record of the variation in size of the trunk during this period showed that the woody trunk made a daily variation practically equivalent to that of the entire tree.

These results show that the cork in one instance was impervious to water and remarkably so to the other solutions. The bast, of course, takes up water readily and is easily penetrated by other solutions, especially the hydroxid and amino-acid. These results may be taken to indicate the possibility of some transpiration through the bark, although this matter was not tested, directly. On May 22 a dendrograph was attached to a tree about $35 \mathrm{~cm}$. in diameter, standing on the north-facing slope north of the laboratory, for the purpose of
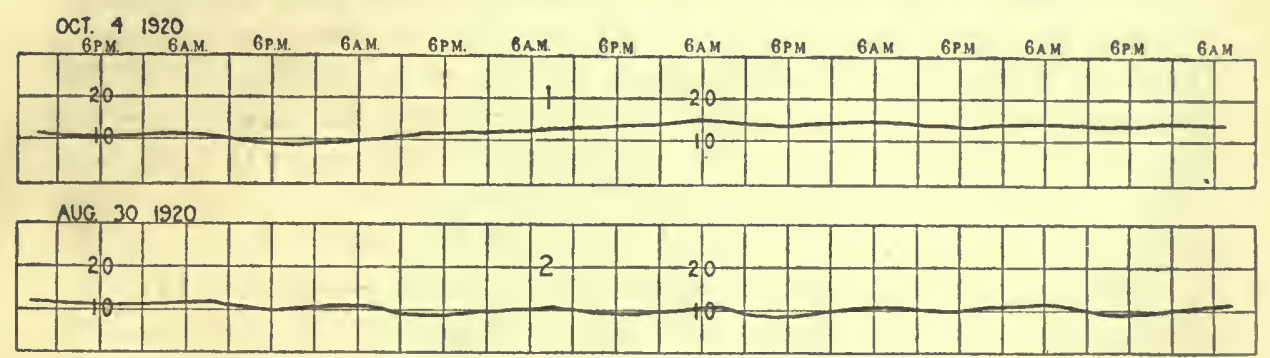

JUNE 211920
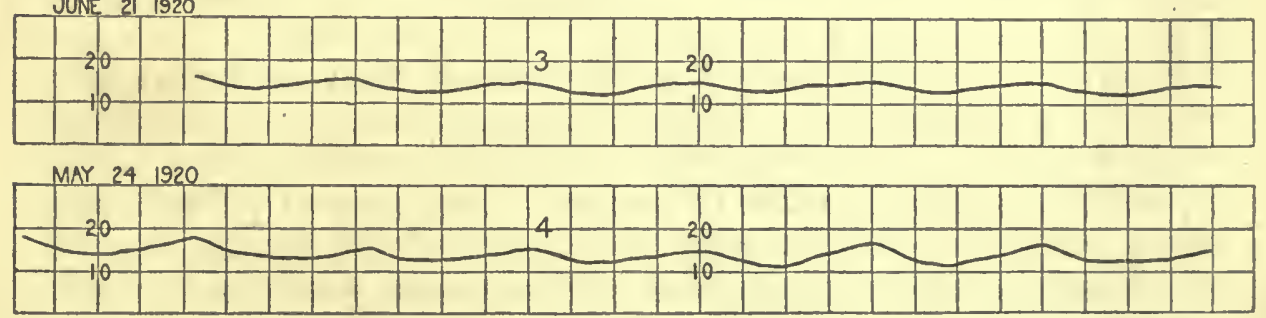

F19. 16.-Dendrographic record of Monterey pine No. 7, to show relative amount of variation in outer and inner parts of trunk. The record for the week beginning May 24 is for the entire trunk, the bearings being taken from an inner thin layer of cork. All other records are from bearings taken from the woody cylinder internal to that of 1918. The range of the daily variation of the inner cylinder is seen to be less in the earlier part of the season and to decrease with the season, as shown in the record for the week beginning August 30. A slight increase was seen in the week beginning October 4. Variations are $X 25$ on a soale of $10 \mathrm{~mm}$. intervals.

measuring the relative expansion of the cork and cambium layers and of the wood. The plan was to attach the instrument to the tree entire and to obtain the record of the daily course of change, and then strip off the bark and growing layer and place the contacts of the instrument on the trunk itself. The trunk was seen to be undergoing daily equalizing variations with no growth in progress. Pine No. 6, a few meters distant, was still showing some accretion, but with a steadily lessening rate. 
After the corky bark and the softer bast had been removed, leaving the woody surface bare for about $5 \mathrm{sq}$. $\mathrm{cm}$. in two places, to give bearings for the contact screw and lever arm, the daily equalizing variation in diameter for a week had an amplitude of $0.2 \mathrm{~mm}$. or one part in 1,750 equivalent to a change of $400 \mathrm{cu}$. $\mathrm{cm}$. in volume. At the end of this time the layers of wood formed in 1920 and 1918 were removed, giving a new reduced diameter of $30 \mathrm{~cm}$. After the bearings were adjusted on these sunken surfaces, the daily variation (which at first was practically equivalent to that of the preceding setting of the whole trunk) decreased until August, when the range of variation was about 1 in 8,750 parts, a range which was maintained with interruptions until the close of the observations in October. The variation in the volume of the wood amounted to about $80 \mathrm{cu} . \mathrm{cm}$. (fig. 16).

In comparison with the above, it was noted that the relative range of the daily equalizing variations in Pine No. 6 decreased in the same ratio, both reaching an approximate minimum about September 20. The behavior of the two diverged after this date. The dendrographic record of the entire trunk of No. 6 shows an increase in the range of daily variation, to which was added a positive increase accompanying a rain on October 6 , which continued until the 12 th, when only the equalizing variations continued, but these were of an amplitude about twice that of the minimum. The woody cylinder of No. 7 interior to the layer of 1919 also showed a swelling of the same duration as in No. 6, but the range of daily variation did not increase.

Thermometers were inserted in the trunk of No. 7 on June 1, one to take the temperature of the bast and cambium region and a second with its bulb at a distance of $12 \mathrm{~cm}$. from the surface, which would be within less than $8 \mathrm{~cm}$. of the center. The course of the temperatures during the day and with the advance of the seasons may be illustrated by the following data: At $8 \mathrm{a} . \mathrm{m}$. the outer thermometer read $12^{\circ} \mathrm{C}$. and the inner $13^{\circ} \mathrm{C}$., at $6 \mathrm{p} . \mathrm{m}$. the readings were identical. On July 2 the outer temperature at $7 \mathrm{a} . \mathrm{m}$. was $14^{\circ} \mathrm{C}$, and the inner $15^{\circ} \mathrm{C}$; ; at $3 \mathrm{p} . \mathrm{m}$. the readings were $17^{\circ} \mathrm{C}$. and $15.5^{\circ} \mathrm{C}$., and at 6 p. m. identical readings of $16^{\circ} \mathrm{C}$. were taken. On August 8 the outer temperature was $12^{\circ} \mathrm{C}$. at $7^{\mathrm{h}} 30^{\mathrm{m}}$ a. m., and the inner $13^{\circ} \mathrm{C}$. At $1^{\mathrm{h}} 30^{\mathrm{m}} \mathrm{p} . \mathrm{m}$. the outer temperature had advanced to $15^{\circ} \mathrm{C}$. and the inner to $13.5^{\circ} \mathrm{C}$. The range of temperature in the tree taken by the two thermometers was $8^{\circ} \mathrm{C}$. during the summer, and the difference between the outer and inner readings reached its maximum of $5^{\circ} \mathrm{C}$. in mid-afternoon, or earlier on still hot days, equalization of the two being reached shortly after sunset, with the outer portion of the tree becoming cooler during the night, so that at sunrise as much of a difference as $1.5^{\circ} \mathrm{C}$. might be seen.

The diameter, therefore, had its minimum measurement at the time when the outer layers of the trunk have a maximum temperature. 
Such high temperature, with its attendant conditions of low relative humidity and the local maximum of air-flow, would of course heighten the rate of water loss of the entire tree. Such water loss would, of course, take place from the entire surface, and although it may be assumed that the rate per unit area from the trunk would be small, it is yet undetermined.

Water is entering the tree through the outer membranes of the roots at all times, in accordance with the balance between the soil moisture content of the soil and the absorbing capacity of the roots. It passes upward by capillarity through the vessels at a rapid rate and through the system of inclosed wood-cells or tracheids at a slower rate. The mass of these woody cells furnishes a structure, however, upon which may be based an explanation of the shrinkage of the trunk.

Such an explanation must take into account the fact that the rate of absorption by the roots shows but little daily variation, due especially to the fact that the temperature of the soil may vary but little at the depth at which the roots lie. The rate of transpiration, however, which may come down to a low minimum during the night fogs characteristic of the region, may rise to a high maximum during a warm sunny day with a marked air-flow. The water thus lost is withdrawn from the wood, either by direct outward exit through the bark or upward through the branches and out through the leaves. In both cases the withdrawal lessens the supply or balance in the system of tracheids.

The wood of the 1919 layer, when freshly taken from the tree in slips less than $2 \mathrm{~mm}$. in thickness, swelled 1 per cent in water and in $\mathrm{NaOH} 0.01 \mathrm{~N}$, while the increase was greater in $\mathrm{HCl} 0.01 \mathrm{~N}$, being 3 per cent of the original thickness. It is thus to be seen that the woody tracts through which water passes upward in the tree may have a water deficit of 1 part in 100 when swelled in water at a time when the actual daily shrinkage amounted to but 1 in 1,700 of the entire diameter. It is highly probable, however, that the deficit is unequally distributed, being greater in the outermost layers.

These and other important physical problems are dealt with in dendrographic measurements being carried on at the Desert Laboratory, at the Coastal Laboratory, and at other places by collaborators. 
43 



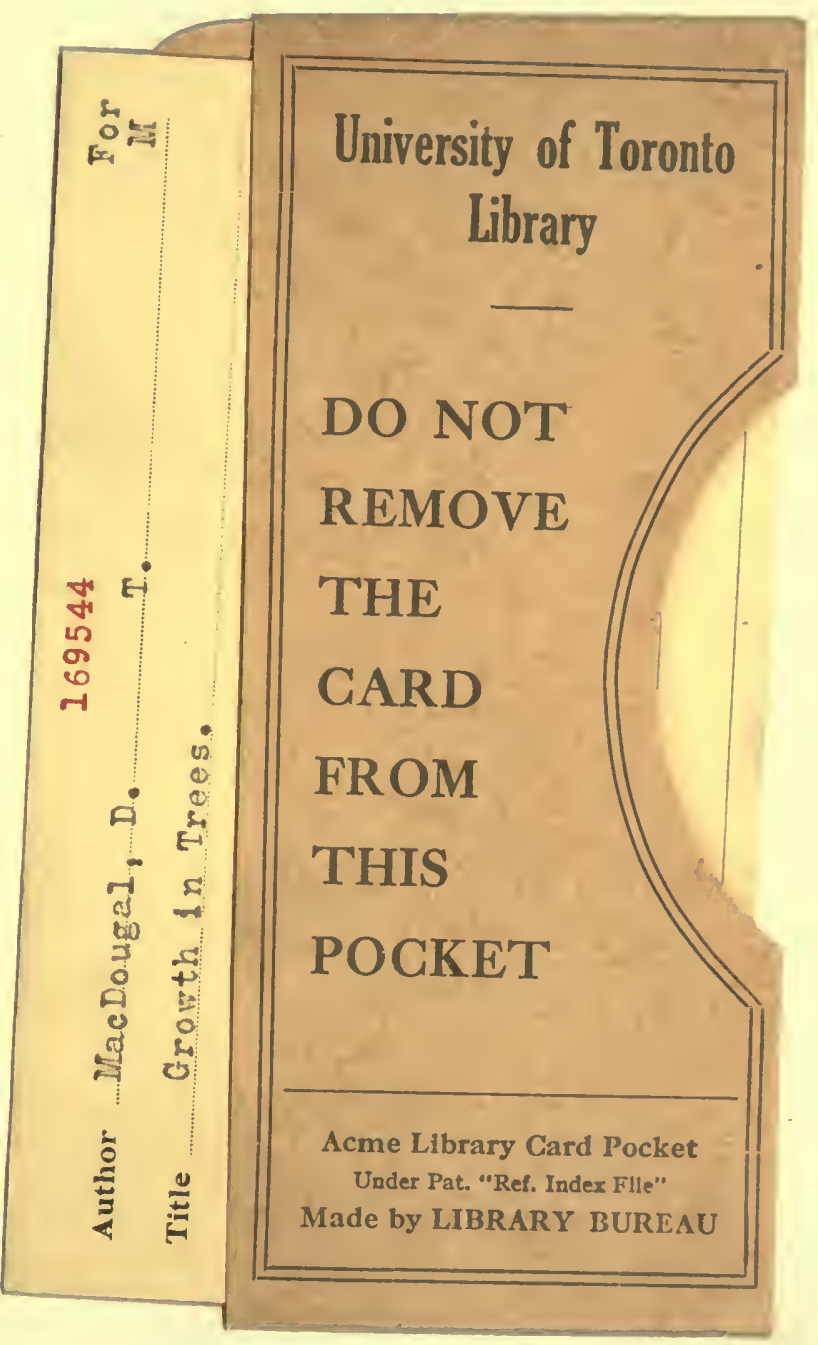


7
3 